\title{
Liquidity Management, Basel Capital Adequacy and Financial Distress Resolution in the Nigerian Banking Industry
}

\author{
Adolphus Joseph Toby, Jibaniya Katon Danjuma \\ Department of Banking and Finance, Rivers State University, Port Harcourt, Nigeria
}

Email address:

toby.adolphus@ust.edu.ng (A. J. Toby)

\section{To cite this article:}

Adolphus Joseph Toby, Jibaniya Katon Danjuma. Liquidity Management, Basel Capital Adequacy and Financial Distress Resolution in the Nigerian Banking Industry. Journal of Finance and Accounting. Vol. 9, No. 4, 2021, pp. 154-171. doi: 10.11648/j.jfa.20210904.16

Received: June 21, 2021; Accepted: July 19, 2021; Published: August 9, 2021

\begin{abstract}
The purpose of this study is to analyze the effect of liquidity management and BASEL capital adequacy on financial distress resolution in Nigeria. The study adopts a unidirectional causal research design within the single-equation dynamic autoregressive distributive lag (ARDL) framework. The empirical analysis is based on annual time series data covering the period from 1986 to 2018 obtained from different Central Bank of Nigeria (CBN) statistical bulletin and Nigeria Deposit Insurance Corporation (NDIC) quarterly as well as the factsheet of the Nigerian Stock Exchange (NSE). The stationarity test results indicate that the study variables are integrated at different levels, with most of them being I(1) series. The ARDL results show that micro-prudential liquidity management has no significant effect on ratio of distressed banks, while the effect of macro-prudential liquidity management on ratio of distressed banks is significant. The results also show that capital adequacy regulation has no significant effect on both ratio of distressed banks and governance/compliance breaches of distressed banks, while it has a significant effect on business risks exposure of the distressed banks and asset quality of distressed banks. Further, monetary policy measures have no significant effect on the level of distress in the Nigerian banking industry. Based on these findings, we conclude that in Nigeria, prudential measures aimed at achieving macro-level financial sector stability have significant policy implications for financial distress resolution. Also, while traditional monetary policy measures are not effective tools for achieving financial sector stability, the effect of capital adequacy regulation on financial distress resolution depends on how the former is measured. The main contribution of this study is the use of Newey-West robust framework, which consistently estimated the effect of liquidity management and BASEL capital adequacy on financial distress resolution even when both heteroskedasticity and autocorrelation are present in the data.
\end{abstract}

Keywords: Financial Distress Resolution, Liquidity Management, BASEL Capital Adequacy, ARDL

\section{Introduction}

The financial sector of any economy occupies a central position in the economic development process. It assists in promoting accelerated economic growth through the process of financial intermediation. There is a positive relationship between real and financial sector development especially in terms of the role of financial intermediation, monetization and capital formation in determining the path and pace of economic growth and development thus making the financial sector very important for the development of any economy [81, 41, 27].

However, there are disruptions which can interfere with the ability of the financial sector to intermediate financial flows might therefore be expected to restrain economic activities. These disruptions might raise the cost of intermediation. In extreme cases, with the failure of a financial institution, valuable banking relationships are lost, and firms may find their access to credit restricted and their ability to invest reduced. Banks take deposits of short maturity and channel same to investors for a long maturity to pay. This maturity mismatch exposes the banks to transformation and asset risks which if not properly managed may create shocks capable of triggering panics that could lead to distress [87]. The fragility of the financial sector makes banks susceptible to systemic risk contagion. A Shock from a single bank when not promptly and adequately 
checked could be propagated to other banks as externality and may result in systemic risks with capability of causing runs. One potential trigger for deposit-runs is fear that a bank may be insolvent. A vital ingredient, therefore, in protecting against runs is for the business and balance sheets of banks to be fundamentally sound.

Banks fail either because they are insolvent or because an aggregate shortage of liquidity can render them insolvent. Banking distress should be managed and controlled in such a way that any pain on depositors, creditors, staff and the economy would be ameliorated $[34,36]$. In responding to the need for stability in the banking sector, the Basel Committee on Banking Supervision issued Basel I, II and III in 1998, 2006 and 2010 respectively to regulate the sector globally [28]. Basel accords are generally aimed at ensuring capital adequacy and liquidity of the banking sector to achieve financial system stability.

Over the years, the banking sector in Nigeria witnessed series of crisis resulting to some failures which led to the loss of funds by a number of depositors without any form of protection. Liquidity shortages and capital inadequacy have been identified to be among the major causes of these distresses and failures. The Central bank of Nigeria (CBN), and the Nigerian Deposit Insurance Corporation have shared responsibility of bank distress and failure resolution. Many research have been conducted to find out why banks distress, with more concentration on the effects of macroeconomic policies on bank distress.

However, only few research studies have been carried out to analyze the joint effects microprudential and macroprudential policies and capital adequacy regulation on bank distress. More so, most of the available literature are on foreign countries with just few on Nigeria. Consequently, there is urgent need to develop early warning models suitable for Nigerian banks to enable early detection of ailments and timely resolution of distress.

\subsection{Statement of the Problem}

It is well documented in the finance literature that prudential policies play a significant role in financial distress resolution. Prudential policies are micro or macro-level regulatory measures that mainly focus on banks' capital and liquidity positions. However, in Nigeria, bank distress and failure have continued to be an issue of great concern for regulators and other stakeholders, despite several regulatory measures and reforms implemented by successive governments to ensure financial system stability. Therefore, examining the effects of various regulatory and prudential measures on financial distress resolution in Nigeria would help quantify the extent of success recorded by these measures and reforms.

Unfortunately, literature review suggests that this area of research is scanty but growing in Nigeria. The few published studies also reported mixed evidence. While some of them found that regulatory and prudential measures such as capital and liquidity ratios have no significant effect on bank distress, others, found that these measures exert a strong effect on financial distress [54, 2, 92], Further, it seems that the effect of regulatory measures on bank distress depends on how the former is measured.

Studies show that while risk-weighted capital ratios and liquidity ratios contain significant predictive information for bank distress, equity ratio has no effect on bank distress [3]. Therefore, there is good reason to consider the impact of liquidity management and capital regulation on financial distress resolution in Nigeria. We argue that considering different liquidity management and capital regulation measures would provide more empirical insight on how financial distress in Nigeria could be finally and effectively resolved.

\subsection{Purpose of the Study}

The purpose of this study is to analyze financial distress resolution in the Nigerian Banking Industry within the framework of liquidity management and Basel capital adequacy using the Autoregressive Distributed Lag model. The empirical analysis in this study would be based on the following hypotheses:

$\mathrm{Ho}_{1}$ : There is no significant relationship between microprudential liquidity management and ratio of distressed banks in Nigeria.

$\mathrm{Ho}_{2}$ : There is no significant relationship between macroprudential liquidity management and ratio of distressed banks in Nigeria.

$\mathrm{Ho}_{3}$ : There is no significant relationship between capital adequacy regulation and ratio of distressed banks in Nigeria.

$\mathrm{Ho}_{4}$ : There is no significant relationship between capital adequacy regulation and business risks exposure of distressed banks in Nigeria.

$\mathrm{Ho}_{5}$ : There is no significant relationship between capital adequacy regulation and the asset quality of distressed banks in Nigeria.

$\mathrm{Ho}_{6}$ : There is no significant relationship between capital adequacy regulation and governance/compliance breaches of distressed banks in Nigeria.

$\mathrm{Ho}_{7}$ : There is no significant relationship between monetary policy and the level of distress in the banking industry in Nigeria.

The rest of the study is structured as follows: The next section contains review of recent empirical studies on the subject matter; section 3 discusses the sample, data, method and models; section 4 contains data analysis and results; and section 5 concludes the study.

\section{Literature Review}

\subsection{Theoretical Review}

\subsubsection{Asset Management Theory}

Asset management theory asserts that banks must seek high returns, reduce risk and make adequate provisions by holding liquid assets. Keynes explained the three motives of holding financial assets to include the transactional, precautionary and speculative motives. The economics and 
finance literature in support of Keynes' assertion analyze four possible reasons for firms to hold liquid assets: the transaction motive; the precautionary motive; the agency motive and the tax motive.

This theory is in support of the need for holding short term assets to cushion the effect of uncertainties in the banking operations and various needs for liquidity. Banks must lend to borrowers who are willing to pay high interest and unlikely to default on their loans, and raise liquidity required without bearing huge costs. Banks are not only funded by assets but they are largely financed by collateralized borrowing which cannot be relied on during financial distress.

\subsubsection{The Friedman-Schwartz Illiquidity Hypothesis}

In their work on the Great Depression, Friedman and Schwartz [45] argue that massive withdrawal of deposits by depositors, illiquidity of assets and Fed Reserve's inability to inject liquidity into the financial system exacerbated the banking crisis, and the collapse of financial institutions. Banks encountered difficulty in converting their assets to liquid form; hence, they were unable to meet depositors' withdrawal demands. In support of this theory, Bernanke in 2002 acknowledged Fed's role in creating the 1930's Great Depression, and that Fed's 2008 response with massive liquidity injection during the Global Financial Crisis is a pointer that Fed learned a lesson from the Great Depression. Coleman [31] in support of the Friedman-Schwartz's Illiquidity Hypothesis confirms that liquidity provides the lubrication to markets and transactions that we need for smooth functioning economy. When liquidity starts to disappear the usefulness of bank deposits also disappears.

\subsubsection{The Illiquidity-Insolvency Debate}

Scholarly debate now revolves around the two competing theories. The traditional scholarship argue that underlying causes of the Great Depression were withdrawals of deposits, illiquidity of assets and the fed Reserve's reluctance to act, a "contagion of fear," a flight to cash holdings and withdrawals en masse drained deposits from banks and pushed financial institution towards collapse. They argue Federal Reserve's mistakes exacerbated the credit crunch [79, 45, 91]. The contending school contends that banks fail because the economy contracted. Asset prices fell, loan defaults rates rose, and banks became insolvent. These fundamental forces accentuated a process of bank liquidation and that began during the $1920 \mathrm{~s}[86,90,25]$.

\subsubsection{Buffer Theory of Capital Adequacy}

The buffer theory predict that a bank approaching the regulatory minimum capital ratio may have an incentive to boost capital and reduce risk in order to avoid the regulatory costs triggered by a breach of the capital requirement [24].

The main purpose of ensuring that bank capital is adequate is to enable banks absorb monetary and macro-economic shocks which their operation is highly sensitive to. However, banks may prefer to hold a buffer of excess capital to reduce the probability of falling under the legal capital requirements, especially if their capital adequacy ratio is very volatile. Capital adequacy has in recent time gone beyond that of banking supervisory instrument to a monetary policy tool of achieving financial stability.

\subsubsection{Financial Regulation and Market Failure}

The major goal of regulation in economic life in general, however, traditionally consists in protecting the (uninformed) consumers against a variety of market imperfections. Problems of market failures also apply to the financial sector and the banking system in particular. The goal of banking regulation and supervision is often explicitly stated as to prevent banks from assuming unacceptably high risks which may endanger the interests of creditors, that is, deposit holders and savers in general.

\subsubsection{Basel III and the Global Reform of Financial Regulation}

Basel III emerged in response to the 2007 - 2008 subprime crisis. To reduce systemic risk, regulators consider both the asset risk through the capital requirements and the transformation risk through two liquidity ratios (one for short-term, Liquidity Coverage Ratio, LCR and one for the Long-term, Net Stable Funding Ratio, NSFR). Basel III aimed at putting in place measures which aim to strengthen microprudential regulation and to introduce macroprudential tools [21].

\subsubsection{Financial Distress and Bankruptcy Cost Theory}

Financial distress is generated by the presence of debt in the capital structure which could lead to bankruptcy. It states that the larger the fixed interest charges created by the use of leverage, the greater the probability of decline in earnings and greater the probability of incurrence of costs of financial distress [53, 78].

\subsubsection{The Modigliani and Miller Theorem}

This theory declares that whether a firm finances itself with debt or equity, there is no difference. It states that the earning power and a firms risk assets can be used to calculate the market value of a company. Bank finance themselves by gaining interest from the deposits and the loans they give which is consistent with the $\mathrm{M}$ and $\mathrm{M}$ theorem. However, there arises a problem when banks could not obtain that interest as they expected. This could put the bank at a risk of getting distressed or even failing.

\subsection{Empirical Review}

The impact of financial distress on commercial banks performance in Kenya was examined. From a population of forty-four banks, a sample of twenty-two banks was selected. The sample included eleven listed banks at the NSE and eleven non listed banks. Data was obtained from the financial statements of the banks and the Central bank of Kenya. Altman's Z score model was used to measure financial distress while return on assets ratio was used to measure financial performance. The study find out that most of the banks under study suffered financial distress where the non-listed banks suffered more from financial distress as compared to the listed 
banks. The study also established that financial distress had a significant effect on financial performance of banks where performance was negatively affected [58].

Angeloni and Faia [8] study the transmission of monetary policy and its interplay with bank capital regulation when banks are risky. Optimizing banks subject to runs are introduced in a macro-model and they find a monetary expansion and a positive productivity shock increase bank leverage and risk. Risk-Based capital requirements amplify the cycle and are welfare detrimental. Within the simple policy rules, the best combination includes anti-cyclical capital ratios (as in Basel III) and a response of monetary policy to asset prices or bank leverage.

Ereza et al [43] conduct empirical analysis of Basel III effects of interest rate on the Kosovo banking system using time series data and linear regression model for average interest rate on loans. They came out with result that interest rate of loans has a strong correlation. There would be increase in interest rate if Basel III is implemented which is in tandem with by Modigliani and Miller's [71] finding that higher cost of equity financing and debt financing will lead banks to increase their lending price as well as cause decline in credit growth.

Kcharem [60] study the impact of Basel III capital requirements on the financial sector and the real economy. The study tried to identify the reasons for regulating banks and introduced the two previous Basel Accords. The study concluded that Basel III capital requirements are still not enough robust to keep abreast of continuous banking and financial developments. In addition the study concluded that the implementation of the new regulatory framework will have both negative and positive repercussions for market participants.

In US, Mayes and Stremmel [66] examine the determinants of bank distress and failure as well as compare the performance of risk weighted capital adequacy measures and simple measures of capital adequacy using two different estimation methods: namely, logistics regression and discrete survival time analysis. Their sample comprises quarterly data collected from FDIC-insured banks covering from 1992 to 2012. Their models incorporate both bank-specific CAMELS indicators and macroeconomic condition. They find amongst others that despite being the focus in BASEL framework, risk-weighted capital adequacy measures do not perform better than a simple leverage ratio as the latter explains bank distress and failure more accurately.

The impact of Basel III regulation on profitability of banks and loan pricing in the United Arab Emirate (UAE was tested. The result of their tests indicates that the implementation of Basel III will decrease banks' profitability. The result also finds that Basel III regulation will lead to a higher loan pricing in UAE [93].

Kinyariro et al [63] examining the relationship between adherence to Basel III accord and financial distress status of commercial banks in Kenya find that capital requirements, leverage requirements and liquidity requirements have a positive relationship with financial distress status of commercial banks in Kenya, hence, Basel III accord requirements positively influence the financial distress of commercial banks in Kenya. The study concluded that the adoption of Basel III influences the financial distress status of commercial banks in Kenya and recommended that commercial banks should develop effective policies to ensure that they implement the Basel III Accord since its implementation would help the banks reduce the probability of financial distress.

Bourattour and Khouaja [21] used panel logit analysis on the data set drawn from the 2008-2010 subprime crises period for US commercial banks to explore the contributions of these measures in reducing banks' failure risk. They find that in the presence of tier one ratio, leverage increases bank failure risk, suggesting that banks underestimate their risk by choosing riskier assets and speculative derivatives. This result points out the importance of considering and supervising the off-balance sheet activity in applying Basel III requirements. In regards to the Net Stable Funding Ratio (NSFR), surprisingly, they found out that its efficiency depends on the bank size. Banks of smaller size are more sensitive to their fundamentals and regulatory requirements. Especially, they are more affected (by risk) when there is a lack of stable funding. Banks of larger size however, from the implicit insurance, are not affected by these elements. Their study provides some support to Basel III, suggesting to regulators: first to choose the leverage ratio as a complimentary constraint for reducing bank regulatory arbitrage. Second, to continue implementing liquidity ratios that provide more buffers against the failure risk for small banks. Large banks taking advantage from "the too big to fail" and "too big to discipline" are not affected by liquidity measures. So, regulators should strengthen supervision and transparency requirements for this banks.

Amahalu et al [7] analyze the effect of capital adequacy on bank financial performance in Nigeria using a panel sample of 14 deposit money banks from 2010 - 2015. The results from fixed effects regression show amongst others that capital adequacy exerts a statistically significant effect on bank financial performance.

Chiaramonte and Casu [29] used several variants of pooled logistic regression model to examine the effect of BASEL III structural liquidity and capital ratios on the probability of banks' failure in 28-member states of the European Union for a period ten years from 2004 to 2013. Their sample comprises 513 banks, with 1,982 bank-year panel observations. Consistent with BASEL III's initiatives on structural liquidity as well as the increased regulatory attention on large and systemically important banks, they find that the probability of banks' failure and distress is negatively associated with banks' liquidity holdings, while the effect of capital ratios is more pronounced only for large banks.

Gaston and Ingmar [47] study how the Basel III regulations namely the capital to Liquidity Coverage Ratio (LCR) is likely to impact bank's profitability (i.e ROA), capital levels and default. They find that liquidity regulations induce a decrease in average probabilities of default; the 
liquidity regulation focusing on maturity mismatches (i.e NSFR) induces a decrease in average probabilities of default using $\mathrm{Z}$ score.

Edem [42] examines liquidity management and performance of Deposit Money Banks in Nigeria (19862011). The study was carried out using Multiple Linear Regression Analysis and find that there is a significant relationship between liquidity management and performance of Deposit Money Banks in Nigeria.

The study finds that during financial crisis, many banks run out of liquidity, and some have to raise funds at a large discount in order to meet up with high pressure of demand for urgent cash. He advocated that financial and nonfinancial institutions revisit their corporate governance policies to accommodate market liquidity risk exposures.

Ayoola and Oboko [10] investigate the effect of corporate governance on financial distress in the Nigerian banking industry and examine the discriminatory power of corporate governance mechanism of the board, audit committee, executive management and auditor in one model for financial distress prediction. Using financial statements of 20 banks between 2005 and 2015, analyzing the data using descriptive statistics and generalize quartile regression model. The study concludes that financial distress can be caused by poor corporate governance.

Altunbas et al [6] employ the panel General Methods of moments (GMM) estimation technique to examine the impact of macroprudential policies on bank risk. They use a large panel dataset comprising 20870 bank-date observations for 3177 banks headquartered in 61 emerging and advanced countries for the period from 1990 to 2012. They find that macroprudential polices have a significant effect on bank risk, and that holding bank-specific characteristics constant, macroprudential policies have more impact in a tightening than in an easing episode. Their findings also indicate that there are differences in banks' responses to changes in macroprudential policies, with small and weakly capitalized banks with a higher share of wholesale funding responding more strongly to macroprudential policy changes.

Bitar et al [19] employ an OLS regression framework to investigate the effect of higher capital ratios on risk reduction, efficiency and profitability of 1,992 banks operating in 39 Organization for European Cooperation and Development (OECD) countries from 1999 to 2013. They find that while both risk-based capital ratios and simple capital ratios enhance bank efficiency and profitability, there is no significant effect of risk-based capital ratios on bank risk. Their results, which hold across different subsamples, alternative measures of risk, efficiency and profitability as well as different estimation methods, also suggest that higher capital ratios may have an adverse effect on the efficiency and profitability of highly liquid banks.

Focusing on Pakistani banking sector, Asharaf and Butt [9] consider effects of both bank-specific factors and macroeconomic variables on non-performing loans within the panel data methodological framework using the random effect model. The study examines three bank-specific factors: namely, credit risk, bank size and capital adequacy ratio and two macroeconomic variables: namely, gross domestic product and inflation. The sample covers the period from 2010 to 2016. They find that capital adequacy ratio, bank size, GDP growth rate and inflation all have a negative effect on non-performing loans (NPL) ratio.

\section{Methodology}

Annual macro-level time series data on liquidity management, capital adequacy regulation and financial distress resolution of commercial banks in Nigeria for the period from 1986 to 2018 were used. Hence, the sample covers a period of 33 years. The sampling period was considered based on data availability; hence purposive sampling method was used. All data were collected from four secondary sources: Central Bank of Nigeria (CBN) statistical bulletin, Nigerian Deposit Insurance Corporation Quarterly Bulletin, National Bureau of Statistics and The Nigerian Stock Exchange Factsheet.

\subsection{Method of Data Analysis}

All empirical analysis in this study was based on dynamic time series methods and models. Specifically, while both Augmented Dickey Fuller (ADF) and Phillip Perron (PP) tests were used to examine the stationarity of our time series data, the ARDL framework was employed for all empirical analysis and hypotheses testing.

\subsection{Model Specifications}

The functional models for the relationships between liquidity management, BASEL capital adequacy and financial distress resolution.

$$
\begin{gathered}
R D B=f(A L R, I D R) \\
R D B=f(M L Q R, L T D R, C R R) \\
R D B=f(C R W A R, C T A R, A C R) \\
E I L=f(C R W A R, C T A R, A C R) \\
N P L=f(C A R 1, C A R 2, C A R 3) \\
E O F=f(C A R 1, C A R 2, C A R 3) \\
R D B=f(M L R, P L R, T B R, M P R)
\end{gathered}
$$

Where;

$R D B=$ Ratio of Distressed Banks

$N P L=$ Non-Performing Loan Ratio of Distressed Banks

$E I L=$ Extent of Insider Lending in Distressed Banks

$E O F=$ Extent of Fraud in Distressed Banks

$I D R=$ Interest to Deposit Ratio

$A L R=$ Assets to Lending (Debt) Rate

$C R R_{D R}=$ Cash Reserve Ratio of Distressed Banks

$M L Q R=$ Minimum Liquidity Ratio

$L T D R=$ Loan to Deposit Ratio

$C R W A R=$ Credit to Risk-Weighted Asset Ratio 
$C T A R=$ Capital to Total Asset Ratio

$A C R=$ Assets to Capital Ratio

$C A R 1=$ BASEL I Capital Adequacy Ratio

$C A R 2=$ BASEL II Capital Adequacy Ratio

$C A R 3=$ BASEL III Capital Adequacy Ratio

$M L R=$ Maximum Lending Rate
$P L R=$ Prime Lending Rate

$T B R=$ Treasury Bills Rate

$M P R=$ Monetary Policy Rate

The simple ARDL parameterizations of the above functional models are given as:

$$
\begin{gathered}
R D B_{t}=\alpha_{0}+\alpha_{1} R D B_{t-1}+\alpha_{2} A L R_{t}+\alpha_{3} A L R_{t-1}+\alpha_{4} I D R_{t}+\alpha_{5} I D R_{t-1}+\epsilon_{t} \\
R D B_{t}=\alpha_{0}+\alpha_{1} R D B_{t-1}+\alpha_{2} M L Q R_{t}+\alpha_{3} M L Q R_{t-1}+\alpha_{4} L T D R_{t}+\alpha_{5} L T D R_{t-1}+\alpha_{6} C R R_{t}+\alpha_{7} C R R_{t-1}+\epsilon_{t} \\
R D B_{t}=\alpha_{0}+\alpha_{1} R D B_{t-1}+\alpha_{2} C R W A R_{t}+\alpha_{3} C R W A R_{t-1}+\alpha_{4} C T A R_{t}+\alpha_{5} C T A R_{t-1}+\alpha_{6} A C R_{t}+\alpha_{7} A C R_{t-1}+\epsilon_{t} \\
E I L_{t}=\lambda_{0}+\lambda_{1} E I L_{t-1}+\lambda_{2} C R W A R_{t}+\lambda_{3} C R W A R_{t-1}+\lambda_{4} C T A R_{t}+\lambda_{5} C T A R_{t-1}+\lambda_{6} A C R_{t}+\lambda_{7} A C R_{t-1}+\epsilon_{t} \\
N P L_{t}=\delta_{0}+\delta_{1} N P L_{t-1}+\delta_{2} C A R 1_{t}+\delta_{3} C A R 1_{t-1}+\delta_{4} C A R 2_{t}+\delta_{5} C A R 2_{t-1}+\delta_{6} C A R 3_{t}+\delta_{7} C A R 3_{t-1}+u_{t} \\
E O F_{t}=\vartheta_{0}+\vartheta_{1} E O F_{t-1}+\vartheta_{2} C A R 1_{t}+\vartheta_{3} C A R 1_{t-1}+\vartheta_{4} C A R 2_{t}+\vartheta_{5} C A R 2_{t-1}+\vartheta_{6} C A R 3_{t}+\vartheta_{7} C A R 3_{t-1}+e_{t} \\
R D B_{t}=\beta_{0}+\beta_{1} R D B_{t-1}+\beta_{2} M L R_{t}+\beta_{3} M L R_{t-1}+\beta_{4} P L R_{t}+\beta_{5} P L R_{t-1}+\beta_{6} T B R_{t}+\beta_{7} T B R_{t-1}+\beta_{8} M P R_{t}+\beta_{9} M P R_{t-1}+u_{t}
\end{gathered}
$$

\subsection{Lag Selection Criteria}

The above econometric models are simple ARDL specifications as there is only one lagged value of both the dependent variable and each of the explanatory variables in the right-hand side of each equation. However, as it is well known, these simple specifications may lead to omitted variable bias as more lagged terms may be required for errors to be white noises. It is typical in time series analysis to select the appropriate lag length based on information criterion. To this end, we employed the Schwarz Information Criterion (SIC). The SIC criterion is specified as follows:

$$
S I C=-2\left(\frac{l}{T}\right)+\frac{k \log (T)}{T}
$$

Where, $l=\log$ likelihood function, $k=$ number of parameters estimated and $T=$ number of observations. Although, there are other information criteria such as Akaike Information Criterion (AIC) and Hannan-Quin Information Criterion (HQIC) that have been widely used in the literature, the SIC is employed because of the body of evidence suggesting that it is the most suitable in small sample [61].

\section{Analysis and Results}

Table 1. Descriptive Statistics for RDB, NPL, EIL, EOF and CRR.

\begin{tabular}{lllllll}
\hline Variable & $\overline{\boldsymbol{x}}$ & $\boldsymbol{\sigma}$ & $\boldsymbol{S}$ & $\boldsymbol{k}$ & $\boldsymbol{J B}$ & $\boldsymbol{p}$-value (JB) \\
\hline RDB & 19.95 & 19.64 & 1.85 & 5.00 & 24.36 & 0.0000 \\
NPL & 15.09 & 11.87 & 0.68 & 2.18 & 3.43 & 0.1798 \\
EIL & 18.75 & 4.11 & 0.81 & 4.66 & 7.38 & 0.0249 \\
EOF & 17.22 & 4.18 & 0.99 & 3.01 & 5.37 & 0.0682 \\
\hline
\end{tabular}

Table 1 shows the descriptive summaries for ratio of distressed banks, non-performing loan ratio, debt to assets ratio, total assets ratio, extent of insider, extent of fraud and cash reserve ratio for the period from 1986 to 2018 .

Table 2. Descriptive Statistics for Explanatory Variables.

\begin{tabular}{lllllll}
\hline Variable & $\overline{\boldsymbol{x}}$ & $\boldsymbol{\sigma}$ & $\boldsymbol{S}$ & $\boldsymbol{k}$ & $\boldsymbol{J B}$ & $\boldsymbol{p}$-value(JB) \\
\hline ALR & 30.15 & 3.21 & 0.01 & 2.46 & 0.40 & 0.8173 \\
IDR & 26.09 & 7.28 & 0.62 & 2.93 & 2.10 & 0.3493 \\
MLQR & 11.65 & 1.29 & 0.12 & 2.40 & 0.57 & 0.7507 \\
LTDR & 65.89 & 12.29 & -0.60 & 2.69 & 2.10 & 0.3496 \\
CRR & 31.61 & 16.96 & 0.15 & 1.66 & 2.60 & 0.2730 \\
CRWAR & 16.25 & 3.64 & -1.34 & 5.93 & 21.67 & 0.0000 \\
CRNAR & 8.34 & 2.60 & 0.56 & 2.21 & 2.58 & 0.2757 \\
CTAR & 16.74 & 2.52 & 0.10 & 3.68 & 0.70 & 0.7062 \\
ACR & 16.37 & 2.89 & -0.13 & 3.31 & 0.23 & 0.8899 \\
CAR1 & 11.73 & 0.71 & -0.68 & 2.09 & 3.68 & 0.1588 \\
CAR2 & 13.83 & 0.95 & 1.24 & 3.71 & 9.16 & 0.0103 \\
CAR3 & 17.47 & 2.06 & 0.90 & 3.75 & 5.19 & 0.0746 \\
MLR & 23.42 & 4.86 & 0.43 & 3.40 & 1.23 & 0.5407 \\
PLR & 18.73 & 3.73 & 0.99 & 4.74 & 9.57 & 0.0084 \\
TBR & 12.56 & 4.60 & 0.79 & 4.49 & 6.54 & 0.0380 \\
MPR & 13.77 & 3.90 & 0.71 & 4.75 & 6.94 & 0.0311 \\
\hline
\end{tabular}

\subsection{Stationarity Tests}

Table 3 present the stationarity/unit root test results for dependent variables. Both Philip-Perron (PP) and Augment Dickey-Fuller (ADF) test statistics are presented. Following a well-established convention in time series analysis, we apply the unit root tests on both the level and first deference series for all variables. For PP tests, the bandwidth selection is based on Newey-West using Bartlett Kernel, while for ADF tests, the lag order selection is based on Schwarz Information Criterion, allowing a maximum of eight lags.

Table 3. Unit Root Tests for Dependent Variables.

\begin{tabular}{lllll}
\hline \multirow{2}{*}{ Variable } & ADF tau-statistic & \multicolumn{3}{l}{ PP Adj-t-statistic } \\
\cline { 2 - 4 } & Level & First Difference & Level & First Difference \\
\hline RDB & $-0.6193(0.4408)$ & $-2.9461(0.0046)$ & $-0.4860(0.4974)$ & $-3.0371(0.0036)$ \\
NPL & $-2.4919(0.1267)$ & $-5.9706(0.0000)$ & $-2.5043(0.1239)$ & $-6.4587(0.0000)$ \\
EIL & $-3.1716(0.0312)$ & $-5.7896(0.0000)$ & $-3.3457(0.0209)$ & $-5.8684(0.0000)$ \\
EOF & $-0.3779(0.5402)$ & $-5.4324(0.0000)$ & $-0.3947(0.5337)$ & $-5.4239(0.0000)$ \\
\hline
\end{tabular}




\begin{tabular}{|c|c|c|c|c|c|}
\hline \multirow{2}{*}{ Variable } & \multicolumn{2}{|l|}{ ADF tau-statistic } & \multicolumn{2}{|l|}{ PP Adj-t-statistic } & \multirow{2}{*}{ Remark } \\
\hline & Level & First Difference & Level & First Difference & \\
\hline ALR & $-2.6530(0.0933)$ & $-6.1679(0.0000)$ & $-2.9054(0.0558)$ & $-7.0619(0.0000)$ & $\mathrm{I}(1)$ \\
\hline IDR & $-2.8916(0.0586)$ & $-3.4899(0.0159)$ & $-2.3332(0.1682)$ & $-3.9831(0.0045)$ & $\mathrm{I}(1)$ \\
\hline MLR & $-4.3476(0.0017)$ & $-7.7706(0.0000)$ & $-4.3488(0.0017)$ & $-7.7706(0.0000)$ & $\mathrm{I}(0)$ \\
\hline LTDR & $-3.0135(0.0443)$ & $-5.8984(0.0000)$ & $-3.0137(0.0442)$ & $-6.9021(0.0000)$ & $\mathrm{I}(0)$ \\
\hline CRR & $-2.6557(0.2652)$ & $-7.3588(0.0000)$ & $-2.6768(0.2510)$ & $-7.4385(0.0000)$ & $\mathrm{I}(1)$ \\
\hline CRWAR & $-5.0784(0.0003)$ & $-7.0800(0.0000)$ & $-4.1190(0.0031)$ & $-10.066(0.0000)$ & $1(0)$ \\
\hline CTAR & $-4.0553(0.0037)$ & $-6.2642(0.0000)$ & $-4.2253(0.0023)$ & $-10.276(0.0000)$ & $\mathrm{I}(0)$ \\
\hline ACR & $-4.7168(0.0007)$ & $-4.8969(0.0005)$ & $-4.2440(0.0022)$ & $-6.2141(0.0000)$ & $\mathrm{I}(0)$ \\
\hline CAR1 & $-1.9700(0.2978)$ & $-4.5585(0.0010)$ & $-2.0576(0.2622)$ & $-4.5552(0.0010)$ & $\mathrm{I}(1)$ \\
\hline CAR2 & $-0.5453(0.8691)$ & $-4.5038(0.0012)$ & $-0.7936(0.8074)$ & $-4.4871(0.0012)$ & $\mathrm{I}(1)$ \\
\hline CAR3 & $-0.2314(0.9893)$ & $-3.6784(0.0392)$ & $-0.2810(0.9878)$ & $-3.7461(0.0339)$ & $\mathrm{I}(1)$ \\
\hline MLR & $-3.2525(0.0260)$ & $-6.9686(0.0000)$ & $-3.3073(0.0229)$ & $-11.057(0.0000)$ & $\mathrm{I}(0)$ \\
\hline PLR & $-5.0444(0.0003)$ & $-5.3423(0.0001)$ & $-5.0593(0.0000)$ & $-9.4856(0.0000)$ & $\mathrm{I}(0)$ \\
\hline MPR & $-2.7071(0.0839)$ & $-6.9398(0.0000)$ & $-2.7733(0.0734)$ & $-6.9398(0.0000)$ & $\mathrm{I}(1)$ \\
\hline
\end{tabular}

Source: EViews 11 Output based on Research Data

( ) contains p-values of test statistic

I(1) indicates stationarity at first difference

$\mathrm{I}(0)$ indicates stationarity at level

Overall, the results suggest that our variables are stationary at different levels, hence, the use of ARDL framework to examine the relationship between liquidity management BASEL capital adequacy and financial distress resolution has been justified.

\subsection{Model Estimation and Hypothesis Testing}

\subsubsection{Results and Analysis of Model 1}

Tables 4 and 5 show the ARDL estimation results for model 1 , which relates ratio of distressed banks to micro-prudential liquidity management. While the Schwarz information criterion (SIC) is used to select the optimum lag order (which selects the model that corresponds to its minimum value), the estimation is based on Newey and West's [73] robust standard errors which are consistent in the presence of unknown heteroskedasticity and serial correlation. Figure 1 shows the model selection results based on Schwarz information criterion (SIC). Figure 2 shows the residual diagnostic plot for the plausibility of the estimated model.

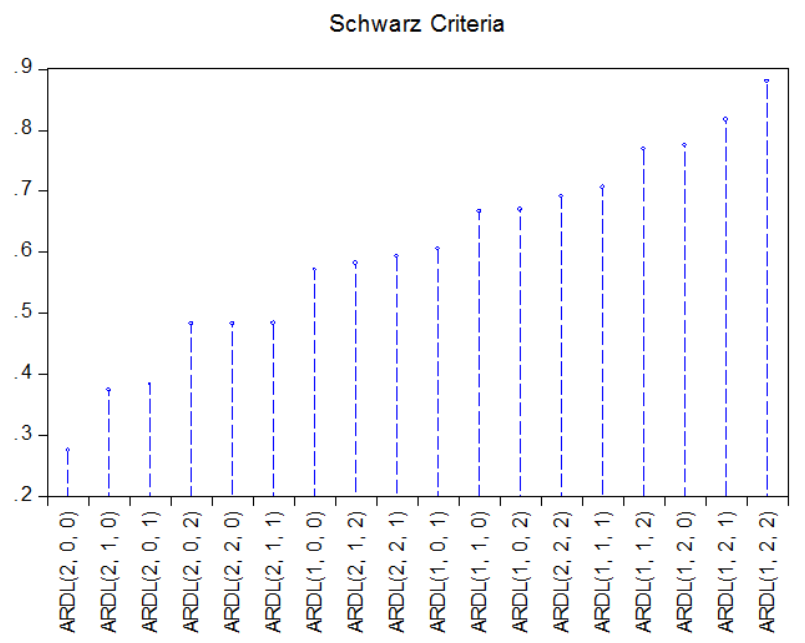

Figure 1. SIC Lag Selection for Model 1.
Table 4. Estimation Results for Model 1; $D V=R D B_{t}$.

\begin{tabular}{lll}
\hline Variable & Coefficient & P-value \\
\hline RDB (-1) & 1.4157 & 0.0000 \\
RDB (-2) & -0.5570 & 0.0087 \\
ALR & -0.7671 & 0.0558 \\
IDR & -0.0309 & 0.8439 \\
INTERCEPT TERM & 3.0989 & 0.0607 \\
Wald (Joint) & 4.0238 & 0.1337 \\
\hline
\end{tabular}

Source: EViews 11 Output Based on Research Data.

Table 5. Diagnostics for Model 1.

\begin{tabular}{ll}
\hline Statistic & Value \\
\hline$R^{2}$ & 0.9137 \\
$\bar{R}^{2}$ & 0.9004 \\
F-statistic & 68.827 \\
Prob (F-statistic) & 0.0000 \\
Durbin-Watson & 1.9691 \\
\hline
\end{tabular}

Source: EViews 11 Output Based on Research Data.

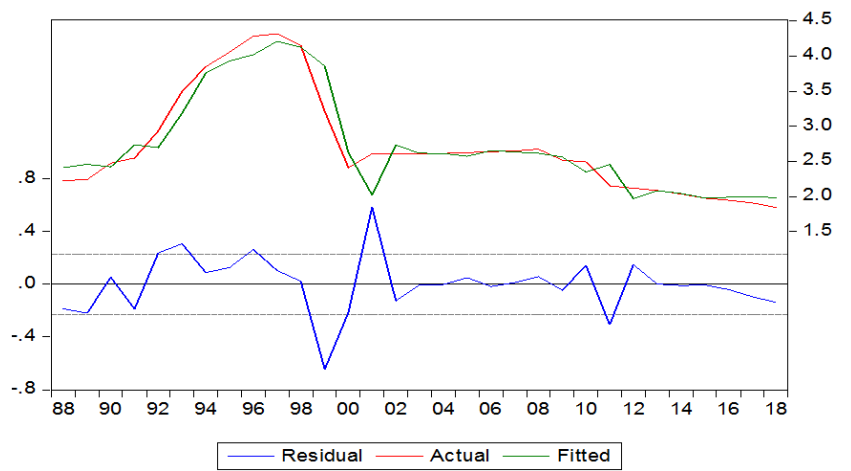

Figure 2. Residual Plot for Model 1.

From Figure 1, we can see that the Schwarz Information Criterion selects an ARDL $(2,0,0)$ model, which implies that a model with 2 lags of the dependent variables as additional regressors is mostly appropriate for our data. Thus, the two lagged dependent variables are important explanatory factors for ratio of distressed banks and must be incorporated 
in the model to avoid specification biases.

From Table 4, the regression results show that the two lagged dependent variables $(\operatorname{RBD} \quad(-1)=1.4157$, pvalue $=0.0000$ and $\operatorname{RBD}(-2)=-0.5570, \mathrm{p}$-value $=0.0087$ ), though have mixed signs, are highly significant, indicating that historical data contain relevant information about future bank distress. The p-value attached to the Wald statistic is 0.1337 , which is higher than all conventional significance levels. Thus, at $95 \%$ confidence level, asset to debt ratio and interest to deposit ratio both have no significant effect on ratio of distressed banks both individually and jointly. Therefore, there is no statistical evidence to reject $H_{01}$, leading us to conclude that micro-prudential liquidity management has no significant effect on ratio of distressed banks in Nigeria.

From Table 5, we can see that our optimum ARDL model is highly fitted $\left(\bar{R}^{2}=0.9004\right)$, with the explanatory factors accounting for as much as approximately $90 \%$ of the observed large variance of the ratio of distressed banks. The F-statistic (P-value $=0.0000)$ is also highly significant, while the Durbin-Watson statistic $(\mathrm{DW}=1.969)$ is almost 2 . This implies that our model is free from specification errors, hence our empirical results are not spurious and are reliable. This is also confirmed by the residual plot in Figure 2 which shows that the fitted line is very much close to the actual, and the estimated errors are stationary.

\subsubsection{Results and Analysis of Model 2}

Tables 6 and 7 show the ARDL estimation results for model 2 , which relates ratio of distressed banks to macro-prudential liquidity management. While the Schwarz information criterion (SIC) is used to select the optimum lag order (which selects the model that corresponds to its minimum value), the estimation is based on Newwy and West's [73] robust standard errors which are consistent in the presence of unknown heteroskedasticity and serial correlation. Figure 3 shows the model selection results based on Schwarz information criterion (SIC). Figure 4 shows the residual diagnostic plot for the plausibility of the estimated model.

Schwarz Criteria (top 20 models)

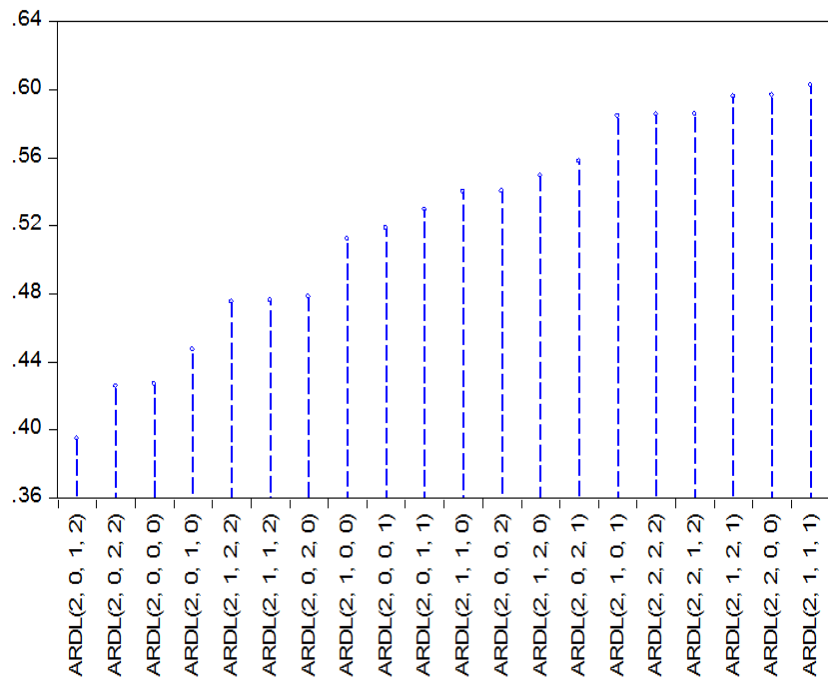

Figure 3. SIC lag selection for model 2.
Table 6. Estimation Results for Model 2; $D V=R D B_{t}$.

\begin{tabular}{lll}
\hline Variable & Coefficient & P-value \\
\hline RDB (-1) & 1.4163 & 0.0000 \\
RDB (-2) & -0.5543 & 0.0018 \\
MLQR & 0.5754 & 0.1337 \\
LTDR & 0.6296 & 0.3748 \\
LTDR (-1) & -0.8292 & 0.0741 \\
CRR & -0.0439 & 0.6621 \\
CRR (-1) & -0.1175 & 0.4195 \\
CRR (-2) & 0.3709 & 0.0756 \\
Intercept Term & -0.9224 & 0.5915 \\
Wald (Joint) & 12.748 & 0.0472 \\
\hline
\end{tabular}

Source: EViews 11 Output Based on Research Data.

Table 7. Diagnostics for Model 2.

\begin{tabular}{ll}
\hline Statistic & Value \\
\hline$R^{2}$ & 0.9375 \\
$\bar{R}^{2}$ & 0.9148 \\
F-statistic & 41.289 \\
Prob (F-statistic) & 0.0000 \\
Durbin-Watson & 2.3982 \\
\hline
\end{tabular}

Source: EViews 11 Output Based on Research Data.

From Figure 3, the Schwarz information criterion prefers an ARDL $(2,0,1,2)$ specification, which implies a model with two lagged values of the dependent variable, one lagged value of loan to deposit ratio and two lagged values of cash reserve ratio as additional explanatory variables. Thus, these additional regressors are important explanatory factors in our empirical model 2 and must be accounted for if reliable empirical results are desired.

From Table 6, the coefficients on RDB (-1) and RDB (-2) are estimated at 1.4163 and -0.5543 with attached $p$-values of 0.0000 and 0.0018 respectively, indicating that the two lagged dependent variables have mixed signs and are highly statistically significant. Also, the Wald statistic in Table 6 is associated with a p-value of 0.0472 , indicating that the joint test is statistically significant at 5\% level. Thus, minimum liquidity ratio, loan to deposit ratio and cash reserve ratio jointly have a significant effect on ratio of distressed banks. Therefore, there is statistical evidence to reject $H_{02}$, leading us to conclude that macro-prudential liquidity management has a significant effect on ratio of banks distressed in Nigeria.

From Table 7, we can see that our optimum ARDL regression model is highly fitted $\left(\bar{R}^{2}=0.9148\right)$ to our time series data, with the explanatory factors accounting for approximately $91 \%$ of the observed variation in ratio distressed banks. The F-statistic $(\mathrm{P}$-value=0.0000) is also highly significant, while the value of Durbin-Watson statistic $(\mathrm{DW}=2.398)$ is not much greater than 2. This, therefore, implies that our model is free from specification errors, hence our empirical results are not spurious and are reliable. This is also confirmed by the residual plot in Figure 4 which shows that the fitted line is very much close to the actual, and the estimated errors are stationary. 


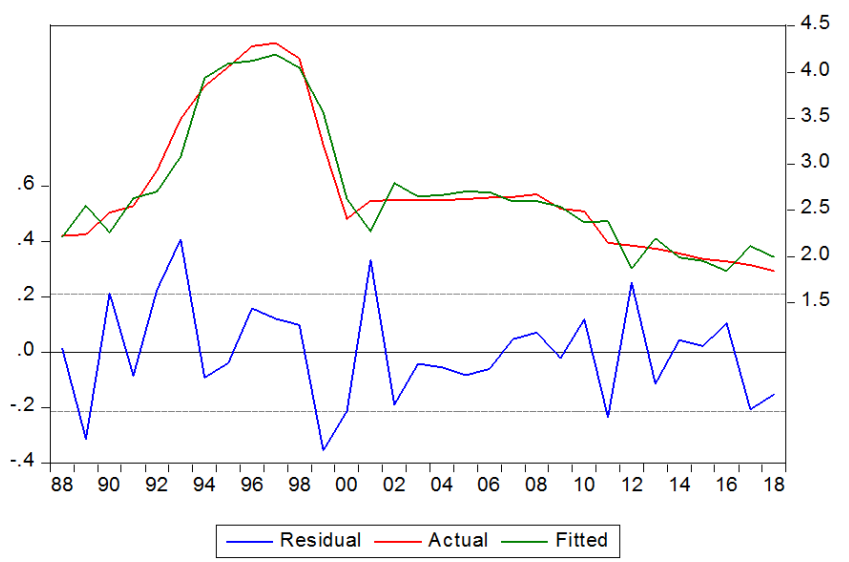

Figure 4. Residual Plot for Model 2.

Table 8. Estimation Results for Model 3; $D V=R D B_{t}$.

\begin{tabular}{lll}
\hline Variable & Coefficient & P-value \\
\hline RDB (-1) & 1.4923 & 0.0000 \\
RDB (-2) & -0.6080 & 0.0094 \\
CRWAR & 0.0873 & 0.3638 \\
CTAR & -0.1495 & 0.7432 \\
ACR & -0.0601 & 0.8902 \\
Intercept Term & 0.6592 & 0.4014 \\
Wald (Joint) & 5.4873 & 0.3593 \\
\hline
\end{tabular}

Source: EViews 11 Output Based on Research Data.

Table 9. Diagnostics for Model 3.

\begin{tabular}{ll}
\hline Statistic & Value \\
\hline$R^{2}$ & 0.9061 \\
$\bar{R}^{2}$ & 0.8874 \\
F-statistic & 48.303 \\
Prob (F-statistic) & 0.0000 \\
Durbin-Watson & 1.9503 \\
\hline
\end{tabular}

Source: EViews 11 Output Based on Research Data.

\subsubsection{Results and Analysis of Model 3}

Tables 8 and 9 show the ARDL estimation results for model 3, which relates ratio of distressed banks to capital adequacy regulation. While the Schwarz information criterion (SIC) is used to select the optimum lag order (which selects the model that corresponds to its minimum value), the estimation is based on Newey and West's [73] robust standard errors which are consistent in the presence of unknown heteroskedasticity and serial correlation. Figure 5 presents the SIC model selection results. Figure 6 presents the graph of the regression residuals.

From Figure 5, The Schwarz information criterion prefers an $\operatorname{ARDL}(2,0,0,0)$ specification, which implies a model with two lagged values of the dependent variable as additional explanatory variables. Thus, RDB (-1) and RDB (2) both must be controlled in our regression if reliable empirical results are desired.

From Table 8 , the coefficients on $R D B(-1)$ and $R D B(-2)$ are estimated at 1.4923 and -0.6080 with attached p-values of 0.0000 and 0.0363 , indicating that the additional regressors statistically significant. The Wald statistic in Table 7 is associated with a p-value of 0.3593 , indicating that the joint test is not statistically significant at all conventional levels.
Thus, credit to risk weighted assets ratio, capital to total assets ratio and assets to capital ratio all have no significant effect on ratio of distressed banks, both individually and jointly. Therefore, there is no statistical evidence to reject $H_{03}$, leading us to conclude that capital adequacy regulation has no significant effect on ratio of distressed bank in Nigeria.

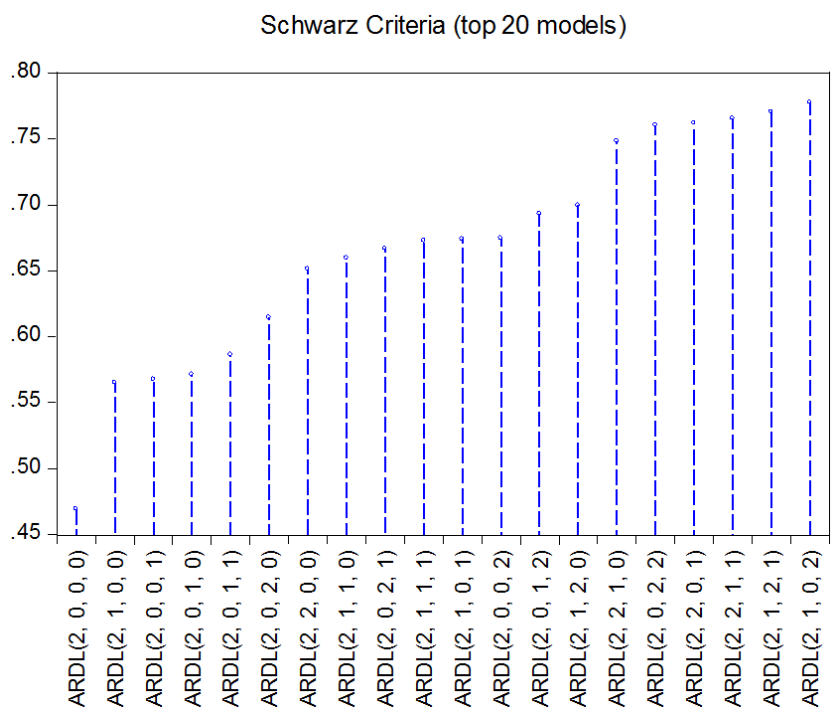

Figure 5. SIC Lag Selection for Model 3 .

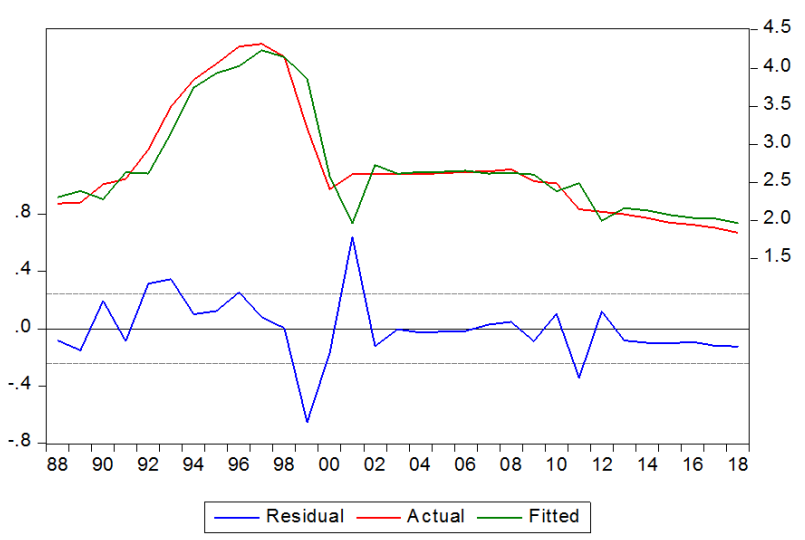

Figure 6. Residual Plot for Model 3.

From Table 9, we can see that our optimum ARDL regression model has a good fit $\left(\bar{R}^{2}=0.8874\right)$, with the explanatory factors contributing approximately $89 \%$ of the observed variation in ratio of distressed banks. The associated probability of F-statistic is 0.0000 , which is quite low indicating that the overall regression is highly significant. Also, the value of Durbin-Watson statistic $(\mathrm{DW}=1.9503)$ is very much close to 2, which implies that our model is free from specification errors, hence our empirical results are not spurious and are reliable. This is also confirmed by the residual plot in Figure 6 which shows that the fitted line is close to the actual, and the estimated errors are stationary.

\subsubsection{Results and Analysis of Model 4}

Tables 10 and 11 show the ARDL estimation results for model 4, which relates business risk exposure of distressed 
banks to capital adequacy regulation. While the Schwarz information criterion (SIC) is used to select the optimum lag order (which selects the model that corresponds to its minimum value), the estimation is based on Newey and West's [73] robust standard errors which are consistent in the presence of unknown heteroskedasticity and serial correlation. Figure 7 presents the SIC model selection results. Figure 8 presents the graph of the regression residuals.

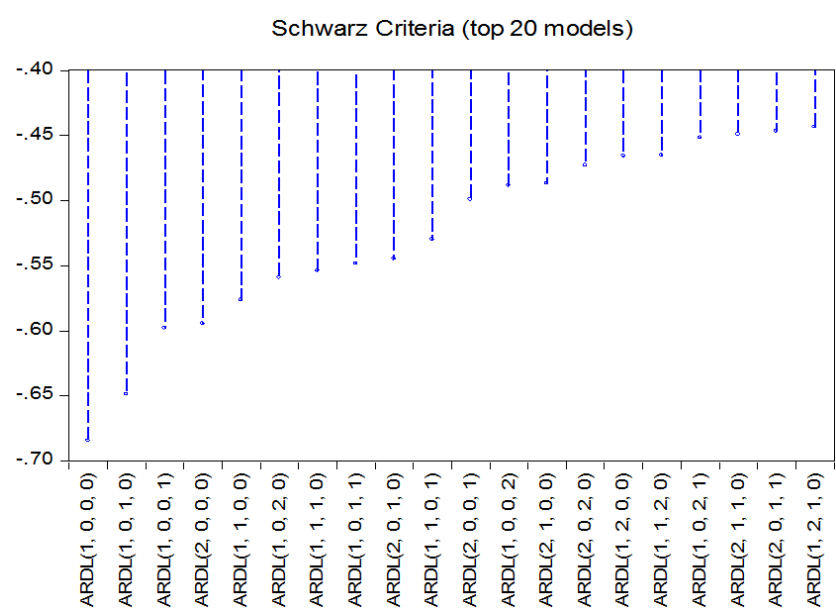

Figure 7. SIC lag selection for model 4.

Table 10. Estimation Results for Model 4; $D V=E I L_{t}$.

\begin{tabular}{lll}
\hline Variable & Coefficient & P-value \\
\hline EIL (-1) & 0.6530 & 0.0007 \\
CRWAR & -0.0394 & 0.3685 \\
CTAR & -0.3740 & 0.0142 \\
ACR & 0.2154 & 0.1954 \\
Intercept Term & 1.5827 & 0.0012 \\
Wald (Joint) & 8.7640 & 0.0326 \\
\hline
\end{tabular}

Source: EViews 11 Output Based on Research Data.

Table 11. Diagnostics for Model 4.

\begin{tabular}{ll}
\hline Statistic & Value \\
\hline$R^{2}$ & 0.5248 \\
$\bar{R}^{2}$ & 0.4544 \\
F-statistic & 7.4561 \\
Prob (F-statistic) & 0.0003 \\
Durbin-Watson & 1.7915 \\
\hline
\end{tabular}

Source: EViews 11 Output Based on Research Data.

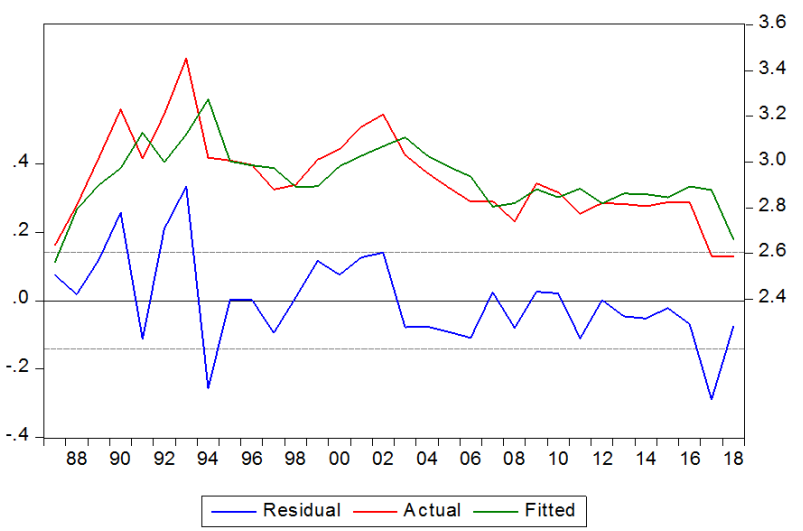

Figure 8. Residual Plot for Model 4.
From Figure 7, the Schwarz information criterion prefers an ARDL $(1,0,0,0)$ specification, which implies a model with one lagged value of the dependent variable as an additional explanatory variable. Thus, EIL (-1) must be controlled in our regression if reliable empirical results are desired.

From Table 10, the coefficient on EIL (-1) is estimated at 0.6530 with an attached p-value of 0.0007 , indicating that the autoregressive coefficient is highly statistically significant. The Wald statistic is associated with a p-value of 0.0326 , indicating that the joint test is statistically significant at $5 \%$ level. Thus, credit to risk weighted assets ratio, capital to total assets ratio and assets to capital ratio jointly have a statistically significant effect on extent of insider lending. Therefore, there is statistical evidence to reject $H_{04}$, leading us to conclude that capital adequacy regulation has a significant effect on business risks exposure of the distressed bank in Nigeria.

From Table 11, we can see that our optimum ARDL regression model has a moderate fit $\left(\bar{R}^{2}=0.4544\right)$, with the explanatory factors contributing approximately $45 \%$ of the observed variation in extent of insider lending. The associated probability of F-statistic is quite low at 0.0003 , indicating that the overall regression is highly significant. Also, although, the value of Durbin-Watson statistic $(\mathrm{DW}=1.7915)$ is lower than 2, our preferred ARDL model, however, has no specification problem given that its estimation is based on HAC standard errors. Hence, our empirical results are not spurious and are reliable. This is also confirmed by the residual plot in Figure 8 which shows that the fitted line is close to the actual, and the estimated errors are stationary.

\subsubsection{Results and Analysis of Model 5}

Tables 12 and 13 show the ARDL estimation results for model 5, which relates asset quality of distressed banks, measured by non-performing loans ratio, to capital adequacy regulation. While the Schwarz information criterion (SIC) is used to select the optimum lag order (which selects the model that corresponds to its minimum value), the estimation is based on Newey and West's [73] robust standard errors which are consistent in the presence of unknown heteroskedasticity and serial correlation. Figure 9 presents the SIC model selection results. Figure 10 presents the graph of the regression residuals.

Table 12. Estimation Results for Model 5; $D V=N P L_{t}$.

\begin{tabular}{lll}
\hline Variable & Coefficient & P-value \\
\hline NPL (-1) & 0.7083 & 0.0000 \\
CAR1 & 0.3419 & 0.8553 \\
CAR2 & -0.7459 & 0.7927 \\
CAR2 (-1) & -6.6716 & 0.1053 \\
CAR2 (-2) & 12.342 & 0.0018 \\
CAR3 & -4.1651 & 0.4533 \\
CAR3 (-1) & 13.816 & 0.0116 \\
CAR3 (-2) & -11.754 & 0.0295 \\
Intercept Term & 2.3751 & 0.2697 \\
Wald (Joint) & 33.361 & 0.0000 \\
\hline
\end{tabular}

Source: EViews 11 Output Based on Research Data. 
Table 13. Diagnostics for Model 5.

\begin{tabular}{ll}
\hline Statistic & Value \\
\hline$R^{2}$ & 0.8598 \\
$\bar{R}^{2}$ & 0.8088 \\
F-statistic & 16.867 \\
Prob (F-statistic) & 0.0000 \\
Durbin-Watson & 1.8617 \\
\hline
\end{tabular}

Source: EViews 11 Output Based on Research Data.

Schwarz Criteria (top 20 models)

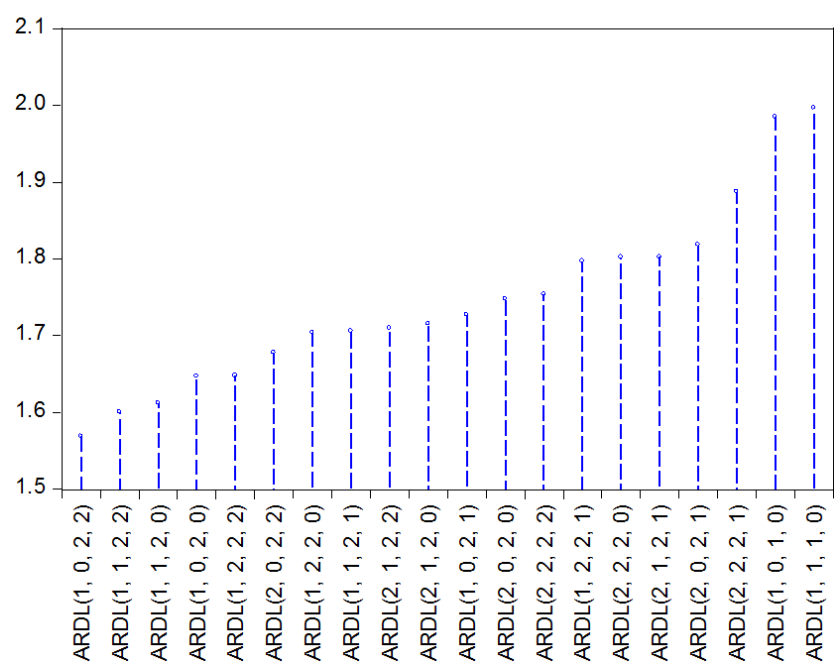

Figure 9. SIC lag selection for model 5 .

From Figure 9, the Schwarz information criterion prefers an ARDL $(1,0,2,2)$ specification, which implies a model with one lagged value of the dependent variable, two lagged values each of CAR2 and CAR3 as additional regressors. Thus, NPL (-1), CAR2 (-1), CAR2 (-2), CAR3 (-1) and CAR3 (-2) all must be controlled in our regression if reliable empirical results are desired.

From Table 12, the coefficients on NPL (-1) is estimated at 0.7083 with an attached $p$-value of 0.0000 , indicating that the autoregressive coefficient is positive and highly statistically significant. The Wald statistic is associated with a p-value of 0.0000 , indicating that the joint test is statistically significant at less than $1 \%$ level. Thus, CAR1, CAR2 and CAR3 jointly have a highly significant effect on non-performing loan ratio. Therefore, there is strong statistical evidence to reject $H_{05}$, leading us to conclude that capital adequacy regulation has a highly significant effect on asset quality of the distressed bank in Nigeria.

From Table 13, we can see that our optimum ARDL regression model is highly fitted to the data $\left(\bar{R}^{2}=0.8088\right)$, with all the explanatory factors contributing approximately $81 \%$ of the observed variation in non-performing loan ratio. Further, the associated probability of F-statistic is 0.0000 , indicating that the overall regression is highly significant. Also, the value of Durbin-Watson statistic ( $\mathrm{DW}=1.8617)$ is close to 2, hence, our preferred ARDL model is free from specification problem. Hence, our empirical results are not spurious and are reliable. This is also confirmed by the residual plot in Figure 10 which shows that the fitted line is very much close to the actual, and the estimated errors are stationary.

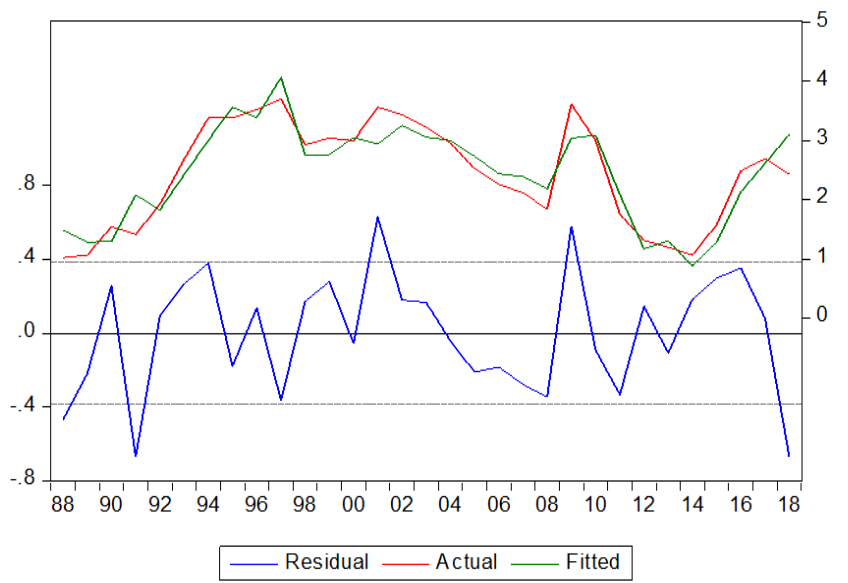

Figure 10. Residual Plot for Model 5.

Schwarz Criteria (top 20 models)

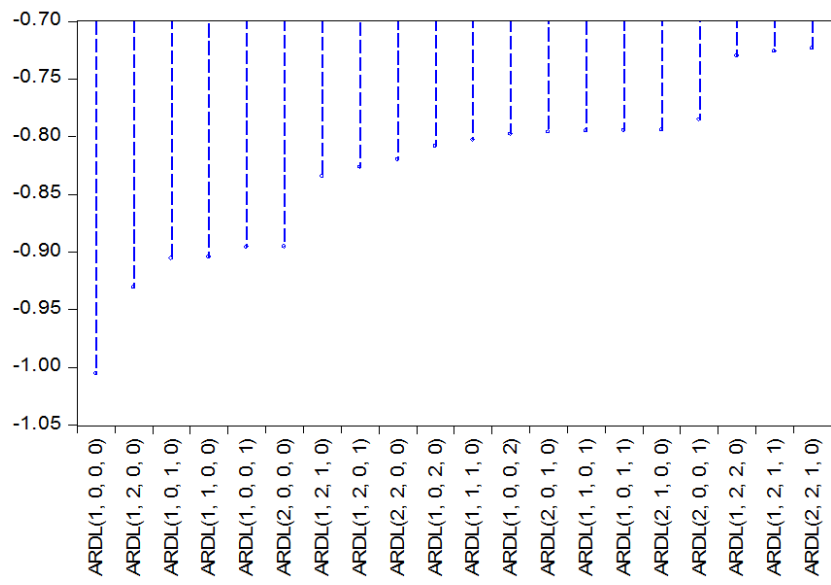

Figure 11. SIC lag selection for model 6.

\subsubsection{Results and Analysis of Model 6}

Tables 14 and 15 show the ARDL estimation results for model 6, which relates asset quality of distressed banks, measured by non-performing loans ratio, to capital adequacy regulation. While the Schwarz information criterion (SIC) is used to select the optimum lag order (which selects the model that corresponds to its minimum value), the estimation is based on Newey and West's [73] robust standard errors which are consistent in the presence of unknown heteroskedasticity and serial correlation. Figure 11 presents the SIC model selection results. Figure 12 presents the graph of the regression residuals.

Table 14. Estimation Results for Model 6; $D V=E O F_{t}$.

\begin{tabular}{lll}
\hline Variable & Coefficient & P-value \\
\hline EOF (-1) & 0.8614 & 0.0001 \\
CAR1 & 0.0110 & 0.9737 \\
CAR2 & -0.0910 & 0.8418 \\
CAR3 & -0.3629 & 0.0964 \\
Intercept Term & 1.6352 & 0.2874 \\
Wald (Joint) & 5.0862 & 0.1656 \\
\hline
\end{tabular}

Source: EViews 11 Output Based on Research Data. 
Table 15. Diagnostics for Model 6.

\begin{tabular}{ll}
\hline Statistic & Value \\
\hline$R^{2}$ & 0.7333 \\
$\bar{R}^{2}$ & 0.6938 \\
F-statistic & 18.568 \\
Prob (F-statistic) & 0.0000 \\
Durbin-Watson & 1.9711 \\
\hline
\end{tabular}

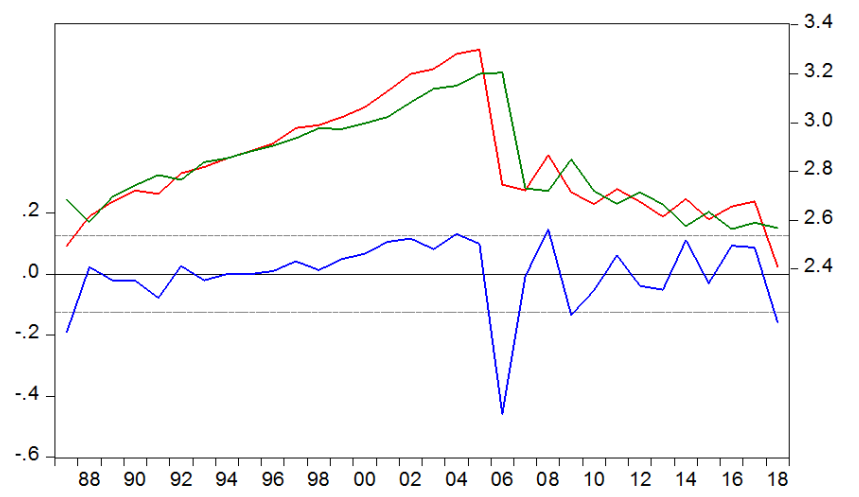

- Residual — Actual — Fitted

Figure 12. Residual Plot for Model 6.

From Figure 11, the Schwarz information criterion prefers an ARDL $(1,0,0,0)$ specification, which implies a model with one lagged value of the dependent variable as an additional regressor. Thus, EOF (-1) must be controlled in our regression if reliable empirical results are desired.

From Table 14, the coefficient on EOF (-1) is estimated at 0.8614 with an attached $p$-value of 0.0001 , indicating that the autoregressive coefficient is positive and highly statistically significant. The Wald statistic has a p-value of 0.1656 , which is higher than any reasonable significance level. Thus, CAR1, CAR2 and CAR3 jointly have no significant effect on extent of fraud. Therefore, there is no statistical evidence to reject $H_{06}$, leading us to conclude that capital adequacy regulation has no statistically significant effect on governance/compliance breaches of distressed banks in Nigeria.

From Table 15 we can see that our optimum ARDL regression model has a good fit $\left(\bar{R}^{2}=0.6938\right)$, with all the explanatory factors contributing approximately $69 \%$ of the observed variation in extent of fraud. Furthermore, the associated probability of F-statistic is 0.0000 , indicating that the overall regression is highly significant. Also, the value of Durbin-Watson statistic ( $\mathrm{DW}=1.9711)$ is almost 2, indicating that our estimated model is free from specification error. Hence, our empirical results are not spurious and are reliable. This is also confirmed by the residual plot in Figure 12 which shows that the fitted line is very much close to the actual, and the estimated errors are stationary.

\subsubsection{Results and Analysis of Model 7}

Tables 16 and 17 show the ARDL estimation results for model 7, which relates ratio of distressed banks to monetary policy measures. While the Schwarz information criterion (SIC) is used to select the optimum lag order (which selects the model that corresponds to its minimum value), the estimation is based on Newey and West's [73] robust standard errors which are consistent in the presence of unknown heteroskedasticity and serial correlation. Figure 13 presents the SIC model selection results. Figure 14 presents the graph of the regression residuals.

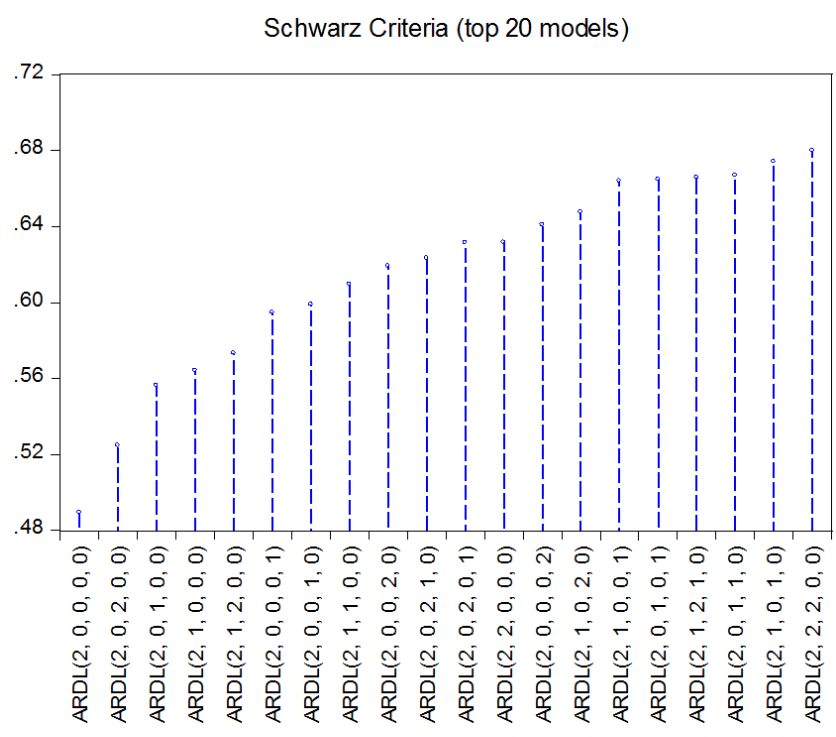

Figure 13. SIC Lag Selection for Model 7.

Table 16. Estimation Results for Model 7; $D V=R D B_{t}$.

\begin{tabular}{lll}
\hline Variable & Coefficient & P-value \\
\hline$R D B(-1)$ & 1.5147 & 0.0000 \\
$R D B(-2)$ & -0.6354 & 0.0009 \\
MLR & 0.1209 & 0.6720 \\
PLR & 0.0880 & 0.6750 \\
TBR & -0.2708 & 0.4365 \\
MPR & 0.5108 & 0.3168 \\
Intercept Term & -0.8863 & 0.4292 \\
Wald (Joint) & 2.2796 & 0.6845 \\
\hline
\end{tabular}

Source: EViews 11 Output Based on Research Data.

Table 17. Diagnostics for Model 7.

\begin{tabular}{ll}
\hline Statistic & Value \\
\hline$R^{2}$ & 0.9143 \\
$\bar{R}^{2}$ & 0.8929 \\
F-statistic & 42.699 \\
Prob (F-statistic) & 0.0000 \\
Durbin-Watson & 2.1044 \\
\hline
\end{tabular}

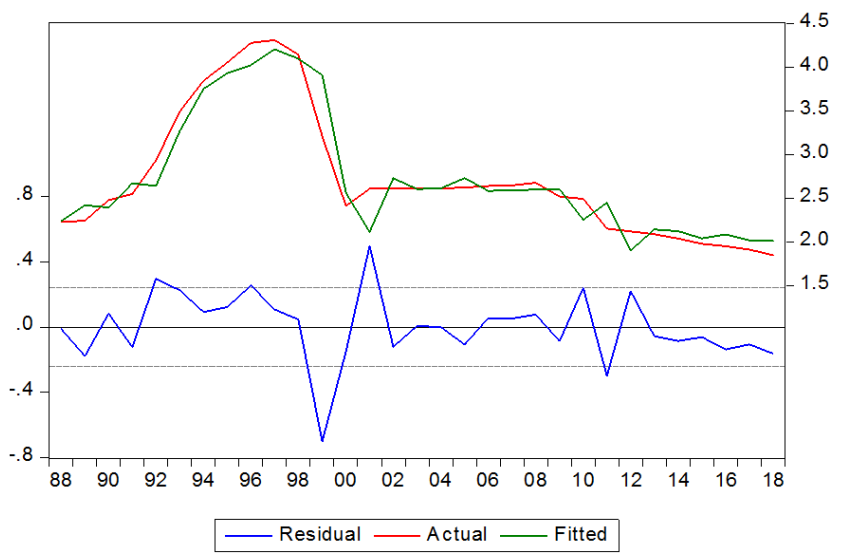

Figure 14. Residual Plot for Model 7. 
From Figure 13, the Schwarz information criterion prefers an ARDL $(2,0,0,0,0)$ specification, which implies a model with two lagged values of the dependent as additional explanatory variables. Thus, both $R D B(-1)$ and $R D B(-2)$ must be controlled in our regression if reliable empirical results are desired.

From Table 16, the coefficients of 1.5147 and -0.6354 with attached p-values of 0.0000 and 0.0009 respectively $R D B$ (1) and $R D B(-2)$ both have positive coefficients and are highly statistically significant. The Wald statistic is accompanied with a p-value of 0.6845 , which is higher than any reasonable significance level. Thus, MLR, PLR, TBR and MPR jointly have no significant effect on ratio of distressed banks. Therefore, there is no statistical evidence to reject $H_{07}$, leading us to conclude that monetary policy has no significant effect on level of distress in the banking industry in Nigeria.

From Table 16, we can see that our optimum ARDL regression model has a good fit $\left(\bar{R}^{2}=0.8929\right)$, with all the explanatory factors contributing approximately $89 \%$ of the observed variation in ratio of distressed banks. Furthermore, the associated probability of F-statistic is 0.0000 , indicating that the overall regression is highly significant. Although, the value of Durbin-Watson statistic ( $\mathrm{DW}=2.1044)$ is marginally more than 2, our estimated model is, however, free from specification error since its estimation is based on NeweyWest [73] standard errors. Hence, our empirical results are not spurious and are reliable. This is also confirmed by the residual plot in Figure 14 which shows that the fitted line is very much close to the actual, and the estimated errors are stationary.

\section{Discussion of Findings}

\subsection{Micro-Prudential Liquidity Management and Ratio of Distressed Banks}

Our first hypothesis states that micro-prudential liquidity management has no significant effect on ratio of distressed banks in Nigeria. Here, micro-prudential management is measured by the joint significance of assets to debt ratio and interest to deposit ratio. Micro-prudential measures focus on strengthening banks against idiosyncratic shocks, hence they are used to minimize the probability of failure of individual banks [32]. Further, financial distress is a function of debt or financial leverage [53]. This implies that micro-prudential management can significantly affect ratio of distressed banks. Thus, our apriori expectation is that the Wald statistic, which tests the joint significance of assets to debt ratio and interest to deposit ratio, is significant so that the above hypothesis would be rejected.

Contrary to our expectation, apriori, our results show that micro-prudential management has no significant effect on ratio of distressed banks. The Wald statistic shown in Table 4 has an estimated value of 4.0238 and an associated p-value of 0.1337 , which is higher than any reasonable statistical level of significance, leading us not to reject the specified null hypothesis. This implies that micro-prudential factors such as assets to debt ratio and interest to deposit ratio do not contain relevant information for predicting financial distress in Nigeria. This evidence, which also suggests that financial distress or probability of banks' failure is not related to idiosyncratic or bank-specific factors, disagrees with the assertions of both crockett [32], and Harris and Raviv [53] as well as the empirical findings of Buehler et al [23] as earlier reviewed.

This finding also implies that banks' distress are caused by systemic risk factors, hence implementing only microprudential measures as means of preventing future bank failure or financial distress and ensuring financial stability would not lead to the desired policy outcome in Nigeria. This finding can also be interpreted in the context of the argument by Goodhart [50] that prudential measures aimed at achieving micro-level stability in financial institutions and financial markets may not be adequate for the economy as a whole.

Moreover, our results show that rather than depending on current balance sheet factors, ratio of distressed banks is autoregressive and depends on its two previous values. The two autoregressive coefficients in Table 4 are both substantial in magnitude and highly statistically significant. This implies that a bank that is unable to fully pay its depositors on time in the current period will also be unable to pay its depositors in full and on time in the next two periods. Thus, any predictive model for bank distress that ignores its autoregressive nature would suffer serious specification biases and would give inaccurate or unreliable results.

\subsection{Macro-Prudential Liquidity Management and Ratio of Distressed Banks}

Our second hypothesis states that macro-prudential liquidity management has no significant effect on ratio of distressed banks in Nigeria. Here, macro-prudential liquidity management is measured by the joint significance of minimum liquidity ratio, loan to total deposit ratio and cash reserve ratio. Macro-prudential management focuses on limiting or preventing risks and costs of systemic crises to the economy [46]. This implies macro-prudential management can significantly affect ratio of distressed banks. Thus, our apriori expectation is that the Wald statistic, which tests the joint significance of monetary lending rate, loan to total deposit ratio and cash reserve ratio, is statistically significant so that the above hypothesis would be rejected.

Consistent with our expectation, apriori, our results show that controlling for two lagged values of ratio of distressed banks, macro-prudential management has a statistically significant effect on ratio of distressed banks. The Wald statistic shown in Table 6 has an estimated value of 12.748 and an associated p-value of 0.0472 , which is lower than 0.05 leading us to reject the specified null hypothesis at $5 \%$ level. This implies that macroprudential measures such as monetary lending rate, loan to total deposit ratio and cash reserve ratio contain relevant information for predicting bank distress in Nigeria. This evidence, which also suggests that financial distress is related to systemic or macroeconomic shocks, 
agrees with Galati and Moessner [46] and the general view that macroprudential measures can effectively reduce risk and costs of financial distress to the economy. This finding is also consistent with the finding by Altunbas et al [6] that macroprudential polices have a significant effect on bank risk.

An implication of this finding is that banks' distress are more related to system-wide financial risk or contagion risk created by interconnectedness and herding behavior of banks, hence implementing macro-level policies aimed at strengthening the entire financial system would effectively reduce the probability of bank failure or financial distress. This finding can also be interpreted in the context of the argument by Goodhart [50] that prudential measures aimed at achieving macro-level stability in financial institutions and financial markets are more important for the economy as a whole.

\subsection{Capital Adequacy Regulation and Ratio of Distressed Banks}

Our third hypothesis states that capital adequacy regulation has no significant effect on ratio of distressed banks in Nigeria. Here, capital adequacy regulation is measured by the joint significance of credit to risk weighted assets ratio, capital to total assets ratio and assets to capital ratio. Bank capital adequacy regulation is a mechanism used to manage or prevent bank failures, hence, it is aimed at minimizing social costs associated with bank insolvency [1, 89]. This implies that capital adequacy regulation can significantly affect ratio of distressed banks. Thus, our apriori expectation is that the Wald statistic, which tests the joint significance of credit to risk weighted assets ratio, capital to total assets ratio and assets to capital ratio, is statistically significant so that the above hypothesis would be rejected.

Contrary to our expectation, apriori, our results show that controlling for two lagged values of ratio of distressed banks, capital adequacy regulation has no significant effect on ratio of distressed banks. The Wald statistic shown in Table 8 has an estimated value of 5.4873 and an associated p-value of 0.3593 , which is substantially higher than any reasonable significance level, leading us not to reject the specified null hypothesis. This implies that capital adequacy measures such as credit to risk weighted assets ratio, capital to total assets ratio and assets to capital ratio do not contain relevant information for predicting bank distress in Nigeria. This evidence, which also suggests that banks' distress is unrelated to their capital requirements, disagrees with the general consensus that bank capital adequacy regulation is aimed at preventing financial distress or managing the social cost of financial crisis. This finding is also not in agreement with Barrell et al [11] who find that higher capital adequacy ratio reduces the probability of bank crisis, Amahalu et al [7] who find that capital adequacy has a significant effect on bank financial performance.

This finding can also be interpreted in the context of Modigliani and Miller's [71] theory, which contends that a firm's source of financing has nothing to do with its value.
Hence, the finding tends to be consistent with our initial finding that bank-specific factors play no significant role in bank distress model. Therefore, there is strong support for the view that rather than idiosyncratic factors, bank distress is more explained by contagion effects and/or systemic risks arising from macroeconomic shocks.

\subsection{Capital Adequacy Regulation and Business Risk Exposure of Distressed Banks}

Our fourth hypothesis states that capital adequacy regulation has no significant effect on business risks exposure of the distressed banks in Nigeria. Here, business risk exposure is measured by extent of insider lending, while capital adequacy regulation is measured by the joint significance of credit to risk weighted assets ratio, capital to total assets ratio and assets to capital ratio. Banks' capital helps to reduce the effects of losses and shocks, hence a decrease in capital relative to assets is a signal for potential difficulties [66]. Similarly, high capital to asset ratios indicate low financial leverage, hence low bank risk [94]. This implies that capital adequacy regulation can significantly affect banks' risk exposure. Thus, our apriori expectation is that the Wald statistic, which tests the joint significance of credit to risk weighted assets ratio, capital to total assets ratio and assets to capital ratio, is statistically significant so that the above hypothesis would be rejected.

Consistent with our expectation, apriori, our results show that controlling for one lagged value of extent of insider lending, which is positive and highly significant, capital adequacy regulation has a statistically significant effect on current extent of insider lending. The Wald statistic shown in Table 10 has an estimated value of 8.7640 and an associated p-value of 0.0326 , which is lower than 0.05 , leading us to reject the specified null hypothesis. This implies that capital adequacy measures such as credit to risk weighted assets ratio, capital to total assets ratio and assets to capital ratio contain relevant information for predicting bank risk exposure in Nigeria. This evidence therefore agrees with the theoretical view that bank capital regulation is aimed at reducing the effects of shocks and losses. This evidence is also consistent with BASEL objectives as well as agrees with Ronn and Verna [44] who show that cross-sectionally variable book value-based capital assets ratios can help to achieve the policy objective of lowering insurer's bankspecific exposure to risk at a tolerable level.

\subsection{Capital Adequacy Regulation and Assets Quality of Distressed Banks}

Our fifth hypothesis states that capital adequacy regulation has no significant effect on assets quality of the distressed banks in Nigeria. Here, assets quality is measured by nonperforming loan ratio, while capital adequacy regulation is measured by the joint significance of capital adequacy ratio BASEL I capital adequacy ratio, BASEL II capital adequacy ratio and BASEL III capital adequacy ratio. Theoretically, capital adequacy regulation helps to sustain banks' 
operations and keep banks running even in the presence of high loan losses and credit risks [9]. This implies a direct relationship between capital adequacy regulation and assets quality. Thus, our apriori expectation is that the Wald statistic, which tests the joint significance of capital adequacy ratio BASEL I, capital adequacy ratio BASEL II and capital adequacy ratio BASEL III, is statistically significant so that the above hypothesis would be rejected.

Consistent with our expectation, apriori, our results show that controlling for one lagged value of non-performing loan ratio, which is positive, substantial in magnitude and highly significant, capital adequacy regulation has a highly statistically significant effect on non-performing loan ratio. The Wald statistic shown in Table 12 has an estimated value of 33.361 and an associated p-value of 0.0000 , which is lower than even 0.01 , leading us to strongly reject the specified null hypothesis. This implies that capital adequacy measures such as capital adequacy ratio BASEL I, capital adequacy ratio BASEL II and capital adequacy ratio BASEL III contain relevant information for predicting asset quality of distressed banks in Nigeria. This evidence therefore agrees with the theoretical view that bank capital regulation helps banks to continue operations even in the presence high loan losses and credit risks. This evidence is also consistent with BASEL objectives as well as agrees with Ashraf and Butt (2019) who find that an inverse relationship between capital adequacy ratio and non-performing loan ratio.

\subsection{Capital Adequacy Regulation and Governance/Compliance Breaches of Distressed Banks}

Our sixth hypothesis states that capital adequacy regulation has no significant effect on governance/compliance breaches of distressed banks in Nigeria. Here, governance/compliance breaches is measured by extent of fraud, while capital adequacy regulation is measured by the joint significance of capital adequacy ratio BASEL I, capital adequacy ratio BASEL II and capital adequacy ratio BASEL III. Capital adequacy regulation provides an incentive for banks to develop a better risk management and internal control systems, hence helping to reduce banks' exposure to large amount of risk and fraud [68]. This implies that capital adequacy regulation and governance/compliance breaches are directly related. Thus, our apriori expectation is that the Wald statistic, which tests the joint significance of capital adequacy ratio BASEL I, capital adequacy ratio BASEL II and capital adequacy ratio BASEL III, is statistically significant so that the above hypothesis would be rejected.

Contrary with our expectation, apriori, our results show that controlling for one lagged value of extent of fraud, which is positive, substantial in magnitude and highly significant, capital adequacy regulation has no statistically significant effect on current extent of fraud. The Wald statistic shown in Table 14 has an estimated value of 5.0862 and an associated pvalue of 0.1656 , which is higher than 0.05 , leading us not to reject the specified null hypothesis. This implies that capital adequacy measures such as capital adequacy ratio BASEL I, capital adequacy ratio BASEL II and capital adequacy ratio
BASEL III has no effect on governance/compliance breaches. This evidence therefore disagrees with the view expressed by Milne [68] that bank capital regulation provides an incentive for banks to develop a better risk management and internal control systems. However, this finding suggests that banks are not substantially constrained by capital adequacy regulations as they make lending decisions that can trigger solvency problems especially during the period of balance sheet expansion. Our finding, however, supports the Modigliani and Miller's [71] claim that capital structure is irrelevant.

\subsection{Monetary Policy and Level of Distress in the Banking Industry}

Our seventh hypothesis states that monetary policy has no significant effect on level of distress in the banking industry. Here, bank distress is measured by ratio of distressed banks, while monetary policy is measured by maximum lending rate, prime lending rate, treasury bills rate and monetary policy rate. Theoretically, the risk-taking channel of monetary policy transmission mechanism argues that low interest rate provides incentives for banks to invest in riskier assets which in turn, increase the probability of bank distress [6]. This implies a significant relationship between monetary policy rate and bank risk taking. Thus, our apriori expectation is that the Wald statistic, which tests the joint significance of maximum lending rate, prime lending rate, treasury bills rate and monetary policy rate, is statistically significant so that the above hypothesis would be rejected.

Contrary to our expectation, apriori, our results show that controlling for two lagged values of ratio of distressed banks, monetary policy has no significant effect on bank distress. The Wald statistic shown in Table 16 has an estimated value of 2.2796 and an associated p-value of 0.6845 , which is much higher than 0.05 , leading us not to reject the specified null hypothesis. This implies that monetary policy measures such as maximum lending rate, prime lending rate, treasury bills rate and monetary policy rate has no effect ratio of the level of bank distress in Nigeria. This evidence disagrees with the risk-taking channel of monetary policy transmission mechanism, which suggests that bank distress or crisis is largely caused by low policy rates. It is also not in consistence with the work of Christiano et al [30] which find that monetary policy affects bank distress. However, this finding largely supports the results by De Nicolo, Dell'Ariccia [33] which imply that the effect of monetary policy on bank distress differs across countries and time but depends on local banking market circumstances and other factors that affect these circumstances.

\section{Conclusions}

There is evidence that Micro-prudential liquidity management has an insignificant effect on ratio of distressed banks in Nigeria. This implies that micro-prudential factors such as assets to debt ratio and interest to deposit ratio do not contain relevant information for predicting financial distress in Nigeria. 
There is evidence that macro-prudential liquidity management has a significant effect on ratio of banks distressed in Nigeria. This implies that macroprudential measures such as monetary lending rate, loan to total deposit ratio and cash reserve ratio contain relevant information for predicting bank distress in Nigeria.

There is evidence that capital adequacy regulation has an insignificant effect on ratio of distressed bank in Nigeria. This implies that capital adequacy measures such as credit to risk weighted assets ratio, capital to total assets ratio and assets to capital ratio do not contain relevant information for predicting bank distress in Nigeria.

There is evidence that capital adequacy regulation has a significant effect on business risks exposure of the distressed bank in Nigeria. This implies that capital adequacy measures such as credit to risk weighted assets ratio, capital to total assets ratio and assets to capital ratio contain relevant information for predicting bank risk exposure in Nigeria.

\section{References}

[1] Acharya, V. V (2003). Is the International Convergence of Capital Adequacy Regulation Desirable? The Journal of Finance, 58 (6), 2745-2782.

[2] Adeyemi, B. (2011). Bank failure in Nigeria: A consequence of capital inadequacy, lack of transparency and nonperforming loans. Banks and Bank systems, 6 (1), 99-109.

[3] Aliero, H. M., Gatawa, N. M., \& Kabiru, A. (2016). The Role of Capital Ratios in Predicting Bank Distress: Evidence from the Nigerian Banks. Advances in Social Sciences Research Journal, 3 (1), 25-40.

[4] Allen, F., \& Santomero, A. (1998). The Theory of Financial Intermediation. Journal of Banking and Finance, 21, 14611485 .

[5] Altman, E. I. (1983). Bankruptcy Costs and the New Code. Journal of Finance. 38 (2), 517-522.

[6] Altunbas, Y., \& Binici, M., Gambacorta, L. (2018). Macroprudential policy and Bank Risk. Journal of International Money and Finance, 81, 203-220.

[7] Amahalu, N., Okoye, E. I., Nweze, C., Chinyere, O., \& Christian, O. (2017). Effect of Capital Adequacy on Financial Performance of Quoted Deposit Money Banks in Nigeria. In Chapter 57 in the Proceedings of 2017 International Conference on African Entrepreneurship and Innovation for sustainable Development (AEISD).

[8] Angeloni, I., \& Faia, E. (2013). Capital Regulation and Monetary Policy with Fragile Banks. Journal of Monetary Economics, 60 (3), 311-324.

[9] Ashraf, N., \& Butt, Q, U. A. (2019). Macroeconomic and Idiosyncratic Factors of Non-Performing Loans: Evidence from Pakistani's Banking Sector. Journal of Finance and Accounting Research, 1 (2), 44-71.

[10] Ayoola, T. J., \& Obokoh, L. (2018). Corporate Governance and Financial Distress in the Banking Industry: Nigerian Experience. Journal of Economics and Behavior Studies, 10 (1), 182-193.
[11] Barrel, R., Davies, E., Karim, D., \& Liadze, I. (2010). Bank Regulation, Property Prices and Early Warning Systems for Banking Crises in OECD Countries. Journal of Banking and Finance, 34 (9), 2255-2264.

[12] Basel Committee on Banking Supervision (2010b). Calibrating Regulatory Minimum Capital Requirements and Capital Buffers: A Top-Down Approach. Bank for International Settlements. www.bis.org

[13] Basel Committee on Banking Supervision (2013). Basel III: The Liquidity Coverage Ratio and Liquidity Risk Monitoring Tools. Bank for International Settlements, Basel.. www.bis.org

[14] Basel Committee on Banking Supervision (2014). Basel III: The Net Stable Funding Ratio. Bank for International Settlements. www.bis.org

[15] Basel Committee on Banking Supervision, (2000). A New Capital Adequacy Framework: Pillar 3 - Market Discipline. Bank for International Settlements. www.bis.org

[16] Basel Committee on Banking Supervision, (2009). Strengthening the Resilience of the Banking Sector. Bank for International Settlements. www.bis.org

[17] Basel Committee on Banking Supervision, (2010d). Basel III: A Global Regulatory Framework for more Resilient Banks and Banking Systems. Bank for International Settlements.www.bis.org

[18] Bernanke, B. S. (1983). Nonmonetary Effects of the Financial Crisis in the Propagation of the Great Depression. The American Review, 73 (3), 257-267.

[19] Bitar, M., Pukthuanthong, K., \& Walker, T. (2018). The Effect of Capital Ratios on the Risk and Efficiency and Profitability of Banks: Evidence from OECD Countries. Journal of International Financial Markets, Institutions and Money, 53, 227-262.

[20] Bordo, M., \& Landon-Lane, J. (2010). The Global Financial Crisis of 2007-08: Is it Unprecedented? National Bureau of Economic Research Working paper no 16589.

[21] Bouattour, L., \& Khouaja, D. (2016). Could Basel III Capital and Liquidity Requirements Avoid Bank Failure?. The International Journal of Business and Finance Research, 10 (4), 63-71.

[22] Bryman, A. (2012). Sampling in Qualitative Research. Social Research Methods, 4, 415-429.

[23] Buehler, K., Samandari, H., \& Mazingo, C. (2009). 'Capital Ratios and Financial Distress: Lessons from the Crisis. McKINSEY Working Papers on Risk. 1-15.

[24] Calem, P., \& Rob, R. (1999). The Impact of Capital Based Regulation on Bank Risk-Taking. Journal of Financial Intermediation, 8 (4), 317-352.

[25] Calomaris, C. W., \& Mason, J. R. (2003). Fundamentals, Panics and Bank Distress during Depression. American Economic Review 93 (5), 1615-47.

[26] Campbell, J. Y., Hilscher, J., \& Szilagyi, J. A. N. (2005). In Search of Distress Risk. The Journal of Finance, 63 (6), 2899-2939.

[27] Carlson, M. A., Thomas, B. K., \& Kurt, F. L. (2008). Distress in the Financial Sector and Economic Activity, Financial Economics Discussion Series. Divisions of Research and Statistics and Monetary Affairs, Federal Reserve Board, Washington D.C. 
[28] Caruana, J. (2010A). Systemic Risk: How to Deal with it. Bank for Intentional Settlements.

[29] Chiaramonte, L., \& Casu, B. (2017). Capital and Liquidity Ratios and Financial Distress. Evidence from European the European Banking Industry. The British Accounting Review, 49 (2), 138-161.

[30] Christiano, L. J., Motto, R., \& Rostagno, M. (2004). The Great Depression and the Friedman Schwartz Hypothesis. National Bureau of Economic Research Working Paper Series.

[31] Coleman, T. P. (2019). Milton Friedman, Anna Schwartz, and A Monetary History of the US. Harris School of Public Policy, University of Chicago.

[32] Crockett, A. (1997). Why is Financial Stability a Public Policy Goal? Federal Reserve Bank of Kansas City. Economic Review, 4, 5-55.

[33] De Nicolo, G., Dell'Ariccia, G., Leaven, L., \& Valencia, F. (2010). Monetary Policy and Bank Risk Taking. SSRN 1654582 .

[34] Diamond, D. W., \& Rajan, R. G. (2002). Bank Bailout and Aggregate Liquidity. American Economic Review, 92 (2), 3841.

[35] Diamond, D. W., \& Rajan, R. G. (2005). Liquidity Shortages and Banking Crisis. The Journal of Finance, 69 (2), 615-647.

[36] Dirk, S. (1999). Contagion Risk in Banking. London School of Economics and Political Science, Financial Markets Group.

[37] Dickey, D. A., \& Fuller, W. A. (1981). Likelihood Ratio Statistics for Autoregressive Time Series with a Unit Root. Econometrica: Journal of the Econometric Society, 49 (4) 1057-1072.

[38] Durbin, J. W., \& Watson, G. S. (1950). Testing for Serial Correlation in Least Squares Regression I. Biometrika, 37 (34), 409-428.

[39] Durbin, J. W., \& Watson, G. S. (1951). Testing for Serial Correlation in Least Squares Regression. II Biometrika, 38 (2), 159-177.

[40] Durbin, J. W., \& Watson, G. S. (1971). Testing for Serial Correlation in Least Squares Regression. III Biometrika, 58 (1), 1-19.

[41] Ebhodaghe, J. U. (1997). Financial Distress and Failure Resolution. Nigeria Deposit Insurance Corporation Quarterly, 7, 3-4.

[42] Edem, D. B. (2017). Liquidity management and performance of Deposit Money Banks in Nigeria (1986-2011): An investigation. International Journal of Economics, Finance and Management Sciences, 5 (3), 146-161.

[43] Ereza, A., Esat, D., Qazim, T., \& Nexhat. K. (2014). Empirical analysis of Basel III effects in interest rate on the Kosovo banking system. European the Science Journal, 10, 259-270.

[44] Ehud, I. R., \& Avinash, K. V. (1989). Risk-Based Capital Adequacy Standards for a Sample of 43 Major Banks. Journal of Banking and Finance, 13, (1), 21-29.

[45] Friedman, M., \& Schwartz A. J. (1963). Monetary History of the United States, 1857-1960, Princeton University Press, Princeton NJ.
[46] Galati, G., \& Moessner, R. (2013). Macroprudential Policy-A Literature Review. Journal of Economic Surveys, 27 (5), 846878.

[47] Gaston, A. G., \& Ingmar, S. (2017). An Empirical Study on the Impact of Basel III Standards on Banks' Default Risks: The Case of Luxembourg. Central Bank of Luxembourg, BCL working papers 79 .

[48] Giordana, G., \& Schumacher, I. (2011). The Impact of the Basel III Liquidity Regulations on the Bank Lending Channel. Papers 61, Central Bank of Luxembourg.

[49] Glaessner, T., \& Ignacio. M. (1995). Incentives and the Resolution of Bank Distress. The World Bank Research Observes, 10 (1), 53-73.

[50] Goodhart, L. M (2015). Brave New World? Macroprudential Policy and the New Political Economy. Review International Political Economy, 22 (2), 280-310.

[51] Granger, C. W. J. (1969). Investigating Causal Relationships by Econometric Models and Cross Spectral Methods. Econometrica: Journal of Econometric Society, 424-438.

[52] Hannan, E. J., \& Quinn, B. G. (1979). The Determination of the Order an Autoregression. Journal of the Royal Statistical Society, Series B (Methodological), 41 (2), 190-195.

[53] Harris, M., \& Raviv, A. (1991). The Theory of Capital Structure. The Journal of Finance, 4 (1), 297-355.

[54] Idowu, E. (2014). Is Increasing Bank Capital the Solution to Improving Bank Liquidity and Preventing Bank Distress in Nigeria. Universal Journal of Applied Science, 2 (4), 83-91.

[55] Jhingan, M. L. (2004). Macro-Economic Theory. $11^{\text {th }}$ Revised Edition Vrinda Publication Ltd.

[56] Johnsen, T., \& Melicher, R. W. (1994). Predicting Corporate Bankruptcy and Financial Distress: Information Value Added by Multinomial Logit Models. Journal of Economics and Business, 46, 269-286.

[57] Kariuki, H. N. (1993). Interest Rate Liberalization and the Allocative Efficiency of Credit: Some Evidence from the Small and Medium Scale Industry in Kenya, Brighton: Institute of Development Studies. University of Sussex.

[58] Kariuki, H. N. (2013). The Effect of Financial Distress of Financial Performance of Commercial Banks in Kenya. University of Nairobi.

[59] Kaufman, G. J. (1985). Bank Runs Benefits and Costs. Cato Journal, 7 (3), 559-582.

[60] Kcharem, N. (2014). Analysis of Basel III capital requirements repercussions on the financial sector and the real economy. Unpublished MSc. Thesis. Aarhus University.

[61] Kilian, L., \& Barsky, R. B. (2001). Do we really know that Oil Caused the Great Stagflation? A Monetary Alternative. NBER Macroeconomics Annual, 16, 137-183.

[62] Kim, D., and Samtomero, A. M. (1988). Risk in Banking and Capital Regulation. The Journal of Finance, 43 (5), 12191233.

[63] Kinyariro, D. K., Meeme, M. M., Muriithi, M. J., \& Maina, J. N. (2016). Implications of Basel III Accord Status of Commercial Banks in Kenya. International Journal of Economics Commerce and Management, 4 (7), 691-705. 
[64] Kothari, C. R. (2004). Research Methodology. In Jaipur (Ed.), Research Methodology. New Delhi: New Age International Limited publishers.

[65] Liadze, I., Barell, R., Karim, D., \& Davis, E. P. (2010). Bank Regulation, Property Prices and Early Warning Systems for Banking Crises in OECD Countries, 2255-2264.

[66] Mayes, D. G., and Stremmel, H. (2014). The Effectiveness of Capital Adequacy Measures in Predicting Bank Distress. SURF Study, 2014/1, Brussels Larcier.

[67] Miles, D. (1995). Optimal Regulation of Deposit Taking Financial Intermediaries. European Economic Review, 39 (7), 1365-13884.

[68] Milne, A. (2001). Minimum capital requirements and the design of the new Basel Accord: a constructive critique. Journal of Financial Regulation and Compliance, 9 (4), 312326.

[69] Miron, J. A. (1994). Empirical Methodology in Macroeconomics: Explaining the Success of Milton Friedan and J. Schwartz's: A Monetary History of the United States, 1867-1960. Journal of Monetary Economic, 34 (1), 17-25.

[70] Mishkin, F. S. (2010). Monetary Policy Flexibility Risk Management and Financial Disruptions. Journal of Asian Economics, 21 (3), 242-246.

[71] Modigliani, F., \& Miller, M. (1958). The Cost of Capital, Corporation Finance and the Theory of Investment. American Economic Review, 48, 261-97.

[72] Morris, S., \& Shin, H. Y. (2000). Rethinking Multiple Equilibria in Macroeconomic Modeling, Yale University. Cowles Foundation Discussion Paper, 1260.

[73] Newey, W. K., \& West, K. D. (1987). Hypothesis Testing with Efficient Method of Moment Estimation? International Economic Review, 28 (3), 777-787.

[74] Nnanna, O. J. (2003). Liquidity Management: Just how much Liquidity is Adequate? Being a Paper Presented at a Conference organized by Nigeria Money Market Association on Liquidity vs Profitability Conflict: The Real issues for Banks. www.expidsc.com/management.html.

[75] Olukotun, G. A., James, O. O., \& Olurunfemi, K. (2013). Bank Distress in Nigeria and the Nigeria Deposit Insurance Corporation Intervention. Global Journal of Management and Business Research Finance. 13 (8), 51-60.

[76] Paroush, P. (1988). The Domino Effect and the Supervision of the Banking Systems. Journal of Finance, 43, 1207- 1215.

[77] Riahi-Balkaoui, A. (1998). The Effects of the Degree of Internationalization on the Firm Performance. International business Review, 3, 315-321.

[78] Riahi-Balkaoui, A. (1999). The Degree of Internalization and the Value of Key Firms: Theory and Evidence Auditing. Journal of International Accounting Taxation, 8 (1), 189-196.
[79] Richardson, G. (2006). Bank Distress during the Great Depression: The Illiquidity-Insolvency Debate Revisited. The National Bureau of Economic Research Working Paper No. 12717.

[80] Sanusi, L. S. (2011). Global Financial Meltdown and the Reforms in the Nigerian Banking Sector. CBN Journal of Applied Statistics, 2 (1), 93-108.

[81] Schumpeter, J. A. (1934). The Theory of Economic Development: An enquiry into Profits, Capital, Credit, Interest and the Business Cycle. New Brunswick (USA) and London (UK): Transaction Publishers.

[82] Schwarz, G. (1978). Estimating the Dimension of a model. Annals of Statistics, 6 (2), 461-464.

[83] Sharpe, W. (1978). Bank Capital Adequate, Deposit Insurance and Security Values. Journal of Financial and Qualitative Analysis, 13 (4), 701-718.

[84] Soludo, C. C. (2004). Consolidating the Nigerian Banking Industry to Meet the Development Challenges of the $21^{\text {st }}$ Century. Being an address delivered to Special Meeting of the Bankers Committee held on the $6^{\text {th }}$ of July, 2004 at CBN Headquarters Abuja.www.cenbank.org

[85] Stiglar, G. (1970). The Optimum Enforcement of Laws. Journal of political economy, 78 (3), 526-36.

[86] Temin, P. (1976). Did Monetary Forces Cause the Great Depression? New York Norton.

[87] Toby, A. J. (2006). Banking System Soundness: Theory and Policy. Pearl Publishers, Port Harcourt Nigeria.

[88] Toby, A. J. (2010). Global Financial Crisis and Bank Management Practices in Nigeria: Survey Findings. Journal of Financial Management and Analysis, 23 (2), 27-51.

[89] Weber, R. G. (2010). New Governance, Financial Regulation and Challenges to Legitimacy: The Example of the Internal Models Approach to Capital Adequacy Regulation. Administrative Law Review, 783-869.

[90] White, E. (1984). Reinterpretation of the Banking Crisis of 1930. Journal Economic History, 44, 119-138.

[91] Wicker, E. (1996). The Banking Panics of the Great Depression. Cambridge, University press.

[92] Yauri, N. M., Musa, J., \& Kaoje, N. A. (2012). Bank Recapitalization in Nigeria: Resuscitating Liquidity or Forestalling Distress? International Journal of Business and Social Science, 3 (10), 12-17.

[93] Yousef. P., Mohammed, M. O., \& Nayyereh. J. (2015). The Impact of Basel III Regulation on Profitability of Banks and Loan Pricing in the United Arab Emirate. Elkasia Journal of Finance and Risk Management, 6 (1). 10-15.

[94] Zopounidis, C., \& Kosmidou, K. (2008). The determinants of banks' profits in Greece during the period of EU financial integration. Managerial Finance, 34 (3), 20-35. 